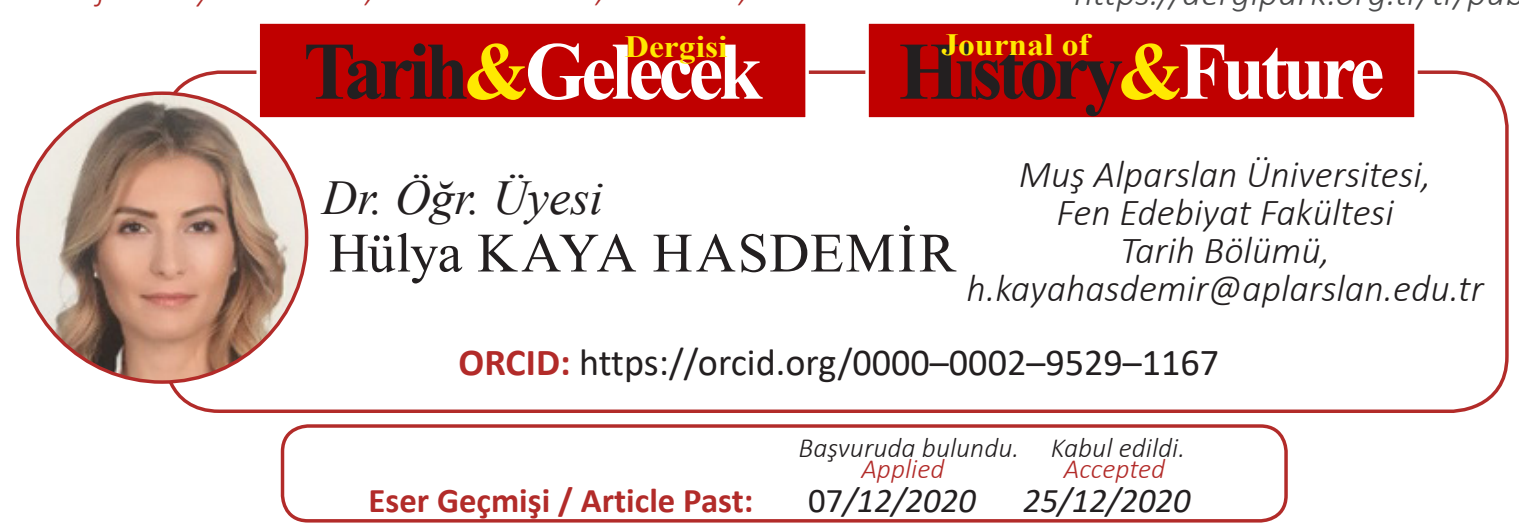

Araştırma Makalesi

DOI: http://dx.doi.org/10.21551/jhf.837038

Research Paper

Orjinal Makale / Orginal Paper

\title{
Kültepe Tabletleri ve Arkeolojik Bulgulara Göre Asur Ticaret Kolonileri Dönemi'nde Eski Anadolu'nun Mutfak Kültürü
}

\author{
Cuisine Culture of the Ancient Anatolia in the Assyrian Trade Colonies \\ Period in the Light of Kultepe Tablets and Archeological Findings
}

\section{$\ddot{O} \mathbf{z}$}

İnsanoğlu dünyada varoluşuyla birlikte barınma, beslenme ve korunma gibi temel ihtiyaçlarla karşılaşmıştır. Bu ihtiyaçlardan beslenme hemen hemen her dönemde birincil önceliği oluşturduğu için en erken çağlardan itibaren birçok arkeolojik buluntu doğrudan ya da dolaylı olarak mutfak kültürü ile ilgili olmuştur. Çalışma konumuzun odak noktasını oluşturan Kültepe'de bulunan tabletler içerisinde Koloni Dönemi'nin beslenme alışkanlıkları ve mutfak kültürü hakkında detaylı bilgi yer almamaktadır. Buna rağmen Kültepe'de gerçekleştirilen arkeolojik kazılarda bulunan muhtelif mutfak gereçleri ve son yıllarda yapılan arkeobotanik ve zooarkeolojik çalışmalar sonucunda elde edilen veriler kullanılarak, Kaniš sakinlerinin mutfak kültürü hakkında daha detaylı sonuçlara ulaşmak mümkün hale gelmiştir.

$\mathrm{Bu}$ zamana kadar Koloni Çağı Anadolu'sunda insanlar tarafindan tanınıp, tüketilen besin maddeleri ile ilgili yapılan çalışmalar, dönem insanlarının beslenme alışkanlıkları ve mutfak kültürlerine dair önemli bilgilere ulaşmamızı sağlamıştır. Ancak Kültepe'de daha önce gerçekleştirilmemiş olan arkeobotanik ve zooarkeolojik çalışmalar sonucunda önemli verilerin elde edilmesi ve yakın zamanlarda yayınlanan Kültepe tabletleri içerisinde besin maddeleri ile ilgili yeni bilgilere rastlanılması konunun yeniden ele alınması gerektiğini düşündürmüştür. $\mathrm{Bu}$ çalışmada Kültepe metinleri, arkeolojik bulgular, arkeobotanik ve zooarkeolojik veriler ile yer yer etnoerkeolojik bilgiler sentezlenerek Eski Anadolu insanının Asur Ticaret Kolonileri Dönemi'nde beslenme alışkanlıkları ve mutfak kültürüne ilişkin bulguların değerlendirilmesi amaçlanmıştır.

Anahtar Kelimeler: Beslenme, Mutfak, Tahıl, Hayvansal Besinler, Etnoarkeoloji. 


\section{Abstract}

People have faced basic needs such as sheltering, nutrition and protection since their existence in the world. As nutrition has been the primary need in almost all periods, many archeological findings have been related to cuisine culture directly or indirectly since the earliest ages. There is not detailed information about the nutritional habits and cuisine culture of the colonial period among the tablets found in Kultepe, which is the focus of our subject of study. However, it is possible to have detailed information on the cuisine culture of the habitants of Kaniš by using the several kitchen tools found and the data obtained as a result of the recent archaeobotanical and zooarcheological studies.

The studies which have been conducted so far on the food stuffs known and consumed by the people in the Colonial Age have provided important information on the nutritional habits and the cuisine cultures of the people of the period. But that important information has been obtained as a result of the archaeobotanical and zooarcheological studies, which have not been conducted so far, and new information has been found in the Kultepe tablets published recently about the food stuffs have made us think that the subject has to be discussed again. In this study, it was aimed to evaluate the findings on the nutritional habits and cuisine cultures of the people in the Ancient Anatolia in the Assyrian Trade Colonies period by synthesizing the Kultepe texts, archeological findings, acheobotanic and zooarchaeological data and, partly, ethnoarchaeological information.

Keywords: Nutrition, Cousine, Grain, Food of Animal Origin, Ethnoarcheology.

\section{Giriş}

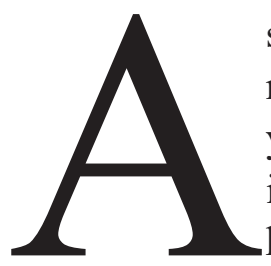

sur Ticaret Kolonileri Çağı'nda Anadolu'daki beslenme alışkanlıkları ve mutfak kültürü hakkında başvurabileceğimiz belgeler, Anadolu'nun ilk yazılı kaynakları olan Kültepe tabletleridir. ${ }^{1}$ Anadolu'nun yerli halkı zaman içerisinde Asurlu tüccarlardan çivi yazısını öğrenmiş ama bu yazı sistemini kendi dillerine uygulamak yerine, onlar da belgelerini Eski Asurca olarak kaydetmişlerdir. Bu durum Anadolu'nun o çağdaki siyasi ve sosyal yapısını, kendi halklarının dillerinde yazılmış kayıtlardan öğrenmemize engel olmaktadır. İ. Albayrak'ın belirttiği gibi “Kültepe tabletleri ışığında Eski Anadolu'yu tanımak, Anadolu'ya biraz da Asurluların gözünden bakmak demektir". ${ }^{2}$ Bu durumda Kültepe metinlerindeki Eski Anadolu'nun mutfak kültürüne dair bilgiler içerisinde Asurluların kendi kültürlerinin tesirinin daha fazla mı olduğu sorusu akla gelebilir. Marks'ın, "kültür; doğanın yaptıklarına karşı insanın ürettiği her şeydir"’3 tanımından yola çıkarak, evlerinden binlerce kilometre uzaklıkta yaşamlarını sürdüren Asurlu tüccarların besin maddelerini sürekli Asur'dan temin etmelerinin imkânsızlığı göz önünde bulundurulursa, Asurluların da yerli halk gibi Anadolu coğrafyasının sunduğu besinleri tercih ettikleri kabul edilebilir.

1 M. Trolle Larsen, The Old Assyrian City-State and Its Colonies, (Copenhagen: Akademisk Forlag, 1976), 224-227.

2 İrfan Albayrak, “Kültepe'de Ele Geçen Vasiyetnamelere Göre Eski Anadolu'da Miras Anlayışı”, ICANAS 38, (2012), 138.

3 Ahmet Uhri, Anadolu Mutfak Kültürünün Kökenleri, (İstanbul: Ege Yayınları, 2016), 10. 
Kültepe'de bulunan arşivlerin büyük kısmı Anadolu'ya ticari amaçlarla gelen Asurlu tüccarlara ait olduğu için bu arşivler içerisindeki belgelerin çoğu ticari kayıtlardan oluşmaktadır. Yani bu belgeler içerisinde Hitit arşivlerinde olduğu gibi mutfak ve besinler hakkında detaylı bilgiye rastlanılmaz. ${ }^{4}$ Oysaki Hitit metinlerinde sulu yemekler, çorba çeşitleri, balla birlikte zeytinyağ 1 veya nar sosu ile zenginleştirilerek kızartılmış et yemekleri, haşlama et, bakla, bezelye, soğan yemeği çeşitlerinin yanı sıra çok sayıda ekmek tarifi detaylı bir şekilde yer almaktadır. ${ }^{5}$

Kaniš halkının beslenme alışkanlıkları ve mutfak kültürü hakkındaki bilgilerimizi doğrudan ya da dolaylı olarak masraf kayıt belgeleri, borç vesikaları, kişisel mektuplar ve arkeolojik kaynaklardan öğrenmekteyiz. Kültepe'de son yıllarda gerçekleştirilen arkeobotanik, paleobotanik ve zooarkeolojik çalışmalar Kaniš sakinlerinin beslenme alışkanlıklarına 1şık tutan yeni bir kaynak olmuştur. ${ }^{6} \mathrm{Bu}$ çalışmalar sonucu elde edilen veriler ile Kültepe tabletlerinden öğrendiğimiz sınırlı bilgiler birleştirilerek, dönem insanının mutfak kültürüne dair daha detaylı sonuçlara ulaşmak mümkün olmuştur.

\section{Kaniš Mutfakları}

Kültepe'de Ib. ve II. yapı katlarında taş ve kerpiç kullanılarak inşa edilen evler, çoğunlukla kullanım amaçlarına göre farklı odalara ayrılmıştır. ${ }^{7}$ Kaniš evlerinde günlük hayatın büyük kısmı zemin katta yer alan, içerisinde ocak, fırın ve tandır bulunan mutfakta (Akadca bìt nuhatimmi) geçmekteydi (Res. 1). ${ }^{8}$ Koloni Dönemi’nde yemek pişirilen alan mutfakla sınırlı kalmamış, mevsim koşulları elverdiği sürece açık avlular mutfak olarak kullanılmıştır. Böylece ocakların açık havada yakılmasıyla duman ve isin etkisi daha hafifletilmiştir. Bazı avlularda ocak ve firın yerlerinin korunamamış olmasına rağmen burada bulunan mutfak gereçleri yemek hazırlığına işaret etmektedir. ${ }^{9}$

4 Yusuf Kılıç, H. Hande Duymuş, "M.Ö. II. Bin Yılda Anadolu'da Besin Maddeleri (Hitit Öncesi Toplumlarda ve Hititlerde)", S. Sertçelik, H. Eroğlu, M. Sarı Güven (ed), Prof Dr. Yavuz Ercan'a Armağan, (Ankara: Turhan Kitapevi), 2008, 339.

5 A. Tuba Ökse, "Modern Mutfakların Eski Anadolu'daki Öncüleri”, Yemek ve Kültür, C. 46, (2017), 80.

6 Andrew Fairbairn, "Preliminary Archaeobotanical Investigations of Plant Production, Consumption, and Trade at Bronze Age Kültepe-Kanesh”, L. Atıcı, F. Kulakoğlu, G. Barjamovic, A. Fairbairn (ed.), Current Research at Kültepe/Kanesh: An Interdisciplinary and Integrative Approach to Trade Networks, Internationalism, and Identity, (Atlanta: Lockwood Press, 2014); Levent Atıc1, "Food and Ethnicity at Kültepe-Kanesh: Preliminary Zooarchaeological Evidence", L. Atıc1, F. Kulakoğlu, G. Barjamovic, A. Fairbairn (ed.), Current Research at Kültepe/Kanesh: An Interdisciplinary and Integrative Approach to Trade Networks, Internationalism, and Identity, (Atlanta: Lockwood Press, 2014); Levent Atıc1, "The Secondary Products Revolution in Light of Textual Evidence from Kültepe-Kanesh Central Turkey", H. Greenfieldpp (ed.), Animal Secondary Products: Domestic Animal Exploitation in Prehistoric Europe, the Near East and the Far East, (Oxford: Oxbow Books Press, 2014); Andrew Fairbairn, Fikri Kulakoğlu ve Levent Atıc1, "Archaeobotanical Evidence for Trade in Hazelnut (Corylus sp.) at Middle Bronze Age Kultepe (c. 1950-1830 BC), Kayseri Province, Turkey", Vegetation History and Archaeobotany, C. 23, S. 2, (2014).

7 Tahsin Özgüç, Kültepe-Kaniş, Asur Ticaret Kolonilerinin Merkezinde Yapılan Yeni Araştırmalar, (Ankara: Türk Tarih Kurumu, 1959), 7.

8 Tahsin Özgüç, Kültepe Kaniš/Neša, (İstanbul: Yapı Kredi Yayınları, 2005), 56; Gojko Barjamovic, Patricia Jurado Gonzalez, vd., "Food in Acient Mesopotamia Cooking the Yale Babylonian Culinary Recipes", A. W Lassen, E. Frahm, K. Wagensonner (ed.), Ancient Mesopotamia Speaks Highlights from the Yale Babylonian Collection, (New Haven: Yale Peabody Museum of Natural History, 2019), 114.

Özgüç, Asur Ticaret Kolonilerinin Merkezinde Yapılan Yeni Araştırmalar, 3; 11. 
Kültepe kazılarda ortaya çıkarılan mutfak yapılarında çanak-çömlek koymak için sıvalı toprak rafların yer alıyor olması mutfakların düzenli tutulmaya çalışıldığını göstermektedir. Bu raflar üzerine aynı tipe giren küçük testiler, üzüm salkımı biçimindeki sepet kulplu bardaklar muntazam sıralar halinde yerleştirilmiştir. Raflara sığamayacak boyutta olan mutfak eşyaları ise ocağın etrafinda ve duvar diplerinde muhafaza edilmiştir. ${ }^{10}$ Kültepe kazılarında ele geçirilen arkeolojik buluntular ve tabletlerden öğrendiğimiz kadarıyla sik kullanılan mutfak gereçleri arasında yemek hazırlığında kullanılan el değirmen taşlar $1^{11}$ ve bıçaklar ${ }^{12}$; pişirmede kullanılan

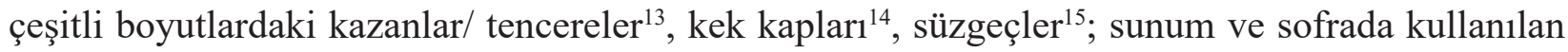
küçük boyutlardaki tabak ve kâseler ${ }^{16}, \operatorname{kadehler}^{17}, \operatorname{kepçeler~}^{18}$, çatallar ${ }^{19}, \operatorname{kaşıklar}^{20}$, meyvelikler $^{21}$ ile depolama ve muhafaza için kullanılan kavanozlar ${ }^{22}$ ve çeşitli boyutlardaki küpler ${ }^{23}$ yer almaktadır.

Kaniš evlerinde Asurlu ve yerli ailelerin sosyal seviyelerini ve yaşam biçimlerini yansıtan mutfaklara ek olarak erzak depolamak için kiler yapılarına da yer verilmiştir. Kilerlerde tahıl ve sıvıların titizlikle depo edildiği anlaşılmaktadır. Bu yapılarda bulunan kap şekillerinin çeşitli oluşu, muhtelif gida maddelerinin depo edildiğini göstermektedir. ${ }^{24}$

Kültepe kazılarında neredeyse her evin mutfak olarak işlev gören büyük odası veya avlusunda firın, ocak ve tandırlara rastlanılmıştır. Boyutları evlere göre değişen bazı ocakların içinde ikinci bir küçük ocak daha yer alıyordu. Böylece aynı ocakta küçük ve büyük tencereler kullanılarak yemek pişiriliyordu. Evlerde bulunan at nalı şeklindeki bu ocakların içinde is veya herhangi bir kararmaya rastlanılmamıştır. Oysaki basit ocak ve tandırların tabanı ile yanları isten kararmıştır. $\mathrm{Bu}$ da gösteriyor ki asıl ateş ocakta ya da tandırda yakılmış buradan elde edilen korlar firınlara

10 Özgüç, Asur Ticaret Kolonilerinin Merkezinde Yapılan Yeni Araştırmalar, $25 ; 2$.

11 Özgüç, Asur Ticaret Kolonilerinin Merkezinde Yapılan Yeni Araştırmalar, 3 vd.

12 Cecile Michel, "A table avec les marchands paléo-assyriens", H. Waetzoldt and H. Hauptmann (ed.), Assyrien im Wandel der Zeiten, Compte rendu des Rencontres Assyriologiques Internationales (CRRAI 39), (Heidelberger: Heidelberger Orientverlag, 1997), 99.

13 İrfan Albayrak, "Kültepe'den Değişik Bir Masraf Listesi”, Archivum Anatolicum, C. 5, S. 1, (2002), 4; L. Gürkan Gökçek, "Kültepe Metinlerinde Geçen Kaplar", Archivum Anatolicum C. 6, S. 2, (2003), 85-86.

14 Von Claus Wilcke, "Die Altassiyrische Testamente", Zeitschrift für Assyriologie (ZA), Band 66, (1976), 224-226.

15 Özgüç, Kültepe Kaniš/Neša, 148 dp. 163.

16 Gökçek, "Kültepe Metinlerinde Geçen Kaplar”, 73.

17 Wilcke, "Die Altassiyrische Testamente", 224-226; Gökçek, "Kültepe Metinlerinde Geçen Kaplar”, 7576.

18 Gökçek, "Kültepe Metinlerinde Geçen Kaplar", 73.

19 Karl Hecker, Guido Kryszat, vd., Kappadokische Keilschrifttafeln aus den Sammlungen der Karlsuniversität Prag, (Prague: Karlsuniversiätt 1998) 278-279.

20 Veysel Donbaz, “Some Remarkable Contracts of I-B Period Kültepe Tablets II”, E. Porada, M. Machteld J., T. Özgüç (ed), Aspects of Art and Iconography: Anatolia and its Neighbors: Studies in Honor of Nimet Özgüc, (Ankara: Türk Tarih Kurumu, 1993) 143-144.

21 Özgüç, Kaniš/Neša, 118.

22 J. Gerrit Dercksen, "Observations on Land Use and Agriculture in Kaneš", C. Michel (ed.), Old Assyrian Studies in Memory of Paul Garelli, Old Assyrian Archives Studies, V. 4, (Leiden: Nederlands Instituut Voor Het Nabije Oosten, 2008) 147.

23 Özgüç, Kültepe Kaniš/Neša, 115.

24 Özgüç, Kültepe Kaniš/Neša, 61; 115. 
taşınmıştır. ${ }^{25}$

Kültepe metinlerinden mutfakta erkeklere göre daha fazla vakit geçiren kadınların aynı zamanda hane halkının beslenmesi için erzak teminini de sağladığ 1 anlaşılmaktadır. ${ }^{26}$ Bugün Anadolu'nun birçok yerinde olduğu gibi Koloni Çağı'nda da kız çocuklara evlenirken verilen çeyizin içeriğinde çeşitli mutfak eşyalarının yer alıyor olması, kadının mutfaktaki rolünü yansıtması açısından önemlidir. ${ }^{27}$

Kültepe tabletleri Kaniš halkının beslenme alışkanlıkları ve tüketilen besinler hakkında neredeyse sessiz kalsa da kazılarda ortaya çıkarılan mutfak yapıları, mutfak gereçleri ve seramiklerin çeşitliliği mutfak kültürünün zenginliğini ortaya koymaktadır. Arkeolojik kazılarda ortaya çıkarılan bulgular o çağlarda insanların nasıl yemek hazırladıkları, nerelerde pişirdikleri ve hangi tip kaplarda tükettikleri konusunda bilgi vermesi açısından önemlidir. ${ }^{28} \mathrm{Bu}$ arkeolojik bulguların yanı sıra Kültepe tabletlerinde geçen çeşitli kap isimleri ve bunların işlevleri dikkate alınarak mutfaklarda pişirilen yemekler ve sofra düzeni hakkında kısıtlı da olsa fikir sahibi olabiliriz. Kültepe tabletlerinde geçen büyük formlardaki kazan ya da tencere işlevi gören kap isimlerinin yanında bir aktarım aracı olan itqurum ${ }^{29}$ "kepçe"nin anılıyor olması büyük boyutlardaki kaplarda pişen yemeklerin ḩuruppum ${ }^{30}$ "tabak" ve šāhuum 31 "kâse" gibi bireysel kaplara aktarılarak tüketildiğini düşündürmektedir. Kepçenin yanı sıra metinlerde geçen itqurum ša qātim "kaşık" kelimesine dayanarak Kaniš sofralarında sulu yemek çeşitlerinin de yer aldığını düşünebiliriz. ${ }^{32}$

Çalışmanın ilerleyen kısımlarında Kültepe kazılarında bulunan arkeolojik malzemeler, arkeobotanik ve zooarkeolojik veriler ile tabletlerde geçen bazı besin maddelerinin Kaniš mutfağında nasıl işlenip, sofralarda hane halkının beğenisine nasıl sunulmuş olabileceği ele alınacaktır.

\section{Tahıl İçerikli Besinler}

İnsanoğlunun yaşadığı mekânın coğrafyası ve iklim şartları Eskiçağlardan beri mutfak kültürünü etkileyip, beslenme alışkanlıklarını şekillendirmiştir. ${ }^{33}$ Besinlerin seçimi ve hazırlama şekilleri toplumdan topluma göre farklılıklar göstermiş ve bu hususta, toplumun yaşadığ 1 coğrafya, iklim, uğraşı alanları, doğal kaynaklar ve ekonomik faktörler rol oynamıştır. ${ }^{34}$ Doğanın cömert

25 Özgüç, Asur Ticaret Kolonilerinin Merkezinde Yapılan Yeni Araştırmalar, 40- 41; 23; Özgüç, Kaniš/ Neša, 56.

26 Cecile Michel, “Asur ve Kaniş’in Kadınları”, F. Kulakoğlu, S. Kangal (ed.), Anadolu’nun Özsözü Kültepe Kaniş-Karumu, (Kayseri: Kayseri Büyükşehir Belediyesi Kültür Yayınları, 2011) 129; 131; Atıc1, "Preliminary Zooarchaeological Evidence", 196.

27 CAD N/2 s. 310'da nudunnû ile ifade edilen çeyiz, ailenin maddi gücüne göre çeşitli mutfak eşyaları, ev eşyaları, gümüş takılar, mücevherler, köle ve bazen taşınmaz mülklerden oluşuyordu. Bkz. K. Rhea Nemet-Nejat, "Women in Ancient Mesopotamia", B. Vivante (ed), Women's Role in Ancient Civilizations, (Westport: Greenwood Press, 1999), 89- 90.

28 Ökse, "Modern Mutfaklar", 77.

29 CAD İ/J, 300.

30 CAD Hู, 256. sayfada "metalden yapılmış bir tabak" olarak açıklanmıştır.

31 CAD Š/1, 105. sayfada "genellikle metalden yapılmış, bir içme veya pişirme kabı olarak" açıklanmıştır.

32 Kültepe metinlerinde geçen çeşitli kap isimleri için bkz. Gökçek, "Kültepe Metinlerinde Geçen Kaplar", $59 \mathrm{vd}$.

33 Kılıç, Duymuş, “Anadolu'da Besin Maddeleri”, 336.

34 H. Hande Duymuş Florioti, “Asur Sarayında Beslenme: Yeni Asur Devri”, Tarih Okulu Dergisi, C. 11, S. 34, (2018), 26. 
davrandığ Anadolu topraklarında özellikle Orta Anadolu Bölgesi'nde iklim tahıl yetiştiriciliğine daha elverişli olduğundan bu bölgede ağırlıklı olarak hububat yetiştirilmiştir. ${ }^{35}$ Yakındoğu'nun kültürel gelişimde buğday ve arpanın oynadığı önemli rolü özellikle vurgulamak gerekir. Doğu Asya kültürlerinin darı ve pirinç üretimine, Yeni Dünya (Amerika) uygarlıklarının mısır ve patates üretimine bağlı olarak yükselişi gibi, Yakındoğu kültürlerinin gelişimi de buğday ve arpaya dayanmaktadır. Bu bağlamda çoğunlukla koyun, keçi ve sığır gibi evcilleştirilmiş hayvanların, besin gereksinimini karşılamadaki payı her ne kadar göz ardı edilemese de buğday ve arpa ana besin maddeleri olmuştur. ${ }^{36}$ Çivi yazılı belgeler ve arkeolojik buluntular Asur Ticaret Kolonileri Dönemi'nde Eski Anadolu insanının temel besin maddelerinin tahıllardan üretildiğine işaret etmektedir. ${ }^{37}$ Kültepe kazılarında bulunan kömürleşmiş tahıl kalıntıları üzerinde yapılan arkeobotanik çalışmalar, Kaniš insanlarının arpa ve buğday çeşitlerinden oluşan protein ağırlıklı bir besin diyetinin olduğunu ortaya çıkarmıştır. ${ }^{38}$

Kültepe metinlerine göre Kaniš tarlalarında yetiştirilen ana hububat türleri še'um 39 "arpa" ve aršātum ${ }^{40}$ "buğday"dır. Bu tahıllar genel olarak utțtutum ${ }^{41}$ sözcüğü ile kaydedilmiştir. ${ }^{42}$ Kültepe'de bulunan buğday türlerinin çoğu ekmek yapımında kullanılan yüksek glütenli buğdaydır. Buna ek olarak emmer ve einkorn buğdaylarının ${ }^{43}$ da sık kullanıldığı tespit edilmiştir. ${ }^{44}$ Buğday türleri esas olarak un üretmek için kullanılırken, arpa türleri daha çok bira üretiminde ve hayvan besiciliğinde tercih edilmiştir.

Tahıllar bazen kabukları soyulmadan dövülerek işlendikten sonra suyla ya da sütle pişirilerek lapa formunda tüketilmiştir. ${ }^{45}$ Lapa şeklinde hazırlanan bu yiyecekler sütten kesilmiş bebeklerin beslenmesinde de kullanılmıştır. Aşıklı, Çatalhöyük ve Çayönü’nde yapılan çalışmalar Neolitik Dönem' de bebeklerin en az 1 yaşına kadar anne sütü ile beslendikten sonra ek gıda olarak tahıl lapası ile beslenildiklerini ortaya koymuştur. ${ }^{46}$ Kültepe metinleri içerisinde eşler arasındaki yazışmalarda

35 Esma Öz, Kültepe Metinleri Işı̆̆ında Eski Anadolu'da Tarım ve Hayvancıllk, (Ankara: Türk Tarih Kurumu, 2014), 9.

36 Antonio Sagona ve Paul Zimansky, Arkeolojik Veriler Işığında Türkiye’nin En Eski Kültürleri M.Ö. 1.000.000-550, (İstanbul: Arkeoloji ve Sanat Yayınları 2018) 35.

37 İrfan Albayrak, "Kültepe Metinlerinde Geçen Besin Maddeleri”, IV. Kayseri ve Yöresi Tarih Sempozyumu Bildirileri, (2003), 60; Öz, Tarım ve Hayvancılık, 9.

38 Fairbairn, "Preliminary Archaeobotanical Investigations", 181.

$39 \mathrm{CAD} \check{\mathrm{S}} / 2,346$.

$40 \mathrm{CAD} \mathrm{A} / 2,308$.

$41 \mathrm{CAD} \mathrm{U} / \mathrm{W}, 349$.

42 Dercksen, “Agriculture in Kaneš”, 144; Öz, Tarım ve Hayvancılık, 12.

43 Emmer (gernik) ve einkorn buğdayları insanoğlu tarafından kültüre alınan ilk buğday türlerindendir. Bereketli Hilal Bölgesi'nde doğal olarak yetişen emmer (gernik) ve einkorn türlerinin genetik ilişkilerinin incelenmesi sonucunda, bu buğday türlerinin Anadolu'daki gen merkezinin Güney Doğu Anadolu Bölgesi'nde yer alan Diyarbakır-Karacadağ yöresi olduğu anlaşılmıştır. Bkz. Mehmet Atak, "Buğday ve Türkiye Buğday Köy Çeşitleri”, Mustafa Kemal Üniversitesi Ziraat Fakültesi Dergisi, C. 22, S. 2, (2017), 74.

44 Fairbairn, "Preliminary Archaeobotanical Investigations", 184.

45 Ali Güveloğlu, "Eski Doğu Toplumlarında Beslenme ve Damak Tadı", İ. Albayrak, H. Erol, M. Çayır (ed.), Cahit Günbattı'ya Armağan, (Ankara: Ankara Üniversitesi Dil ve Tarih-Coğrafya Fakültesi Yayınlar1, 2015) 121.

46 Metin Özbek, Çayönü’nde İnsan, (İstanbul: Arkeoloji ve Sanat Yayınları, 2004) 28; Metin Özbek, 
çocukların beslenmesine aile bireyleri tarafından özen gösterildiği görülmektedir. Bu diyaloglardan birini içeren Kt o/k 77 numaralı belgede Ennum-Aššur karısı Kunaniya'yı "çocuğu aç bırakma" diyerek uyarmıştır. ${ }^{47} \mathrm{Bu}$ durum göz önüne alındığında Kaniš’te sütten kesilen bebeklerin ve küçük yaştaki çocukların beslenmesinde öğütülmüş tahıllardan hazırlanan lapa ve benzeri yumuşak yiyeceklerin tercih edilmiş olabileceği düşünülmektedir.

\subsection{Ekmek}

İnsanoğlunun besin yelpazesinde geniş yer tutan tahıllardan üretilen en önemli gıda maddesi ekmek olmuştur. Tarihin neredeyse tüm dönemlerinde sosyal sınıf ayrımı olmadan tüketilen temel besinlerden biri olan ekmek, çivi yazılı belgelerde Sumerce NINDA ${ }^{48}$ ideogramı ile geçerken, Akadca k $a u^{49}$ terimi ile anılmıştır.

Metinlerde ekmeğin genellikle et, soğan ve diğer besin maddelerinin beraberinde kaydedilmesi pişirilen yemeğin yanında ekmeğin katık edildiğini düşündürmektedir. ${ }^{50}$ Kültepe metinlerinden edinilen bilgiye göre farklı tahıllar kullanılarak ekmek üretimi çeşitlendirilmiştir. Arpa unu kullanılarak ekmek üretilse de buğday unundan yapılan ekmek daha fazla tercih edilmiştir. ${ }^{51}$

ICK I, 181 numaralı belge Koloni Dönemi'nde tüketilen ekmek çeşitleri açısından oldukça zengin bilgi içermektedir. Belgede NINDA ideogramı ile gösterilen normal ekmeğin dışında

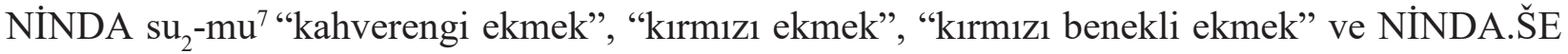
"arpa ekmeği" gibi ekmek çeşitleri de kaydedilmiştir. Aynı metinde, sözlüklerde daha çok bir kek çeşidi olarak açıklanan kukkum ${ }^{52}$ ekmeği ve tahšĭmum ${ }^{53}$ ekmeği de geçmektedir. ${ }^{54}$ Yeni Asur Dönemi'ne ait olan SAA 7, 200; 202 ve 218 numaralı belgelerde Asur tapınağına sunulan besin maddeleri arasında "yağlı ekmek" tabirinin geçmesinden, dönemde ekmeğe katık edilen besinler arasında yağın da olduğu anlaşılmaktadır..$^{55}$

Kültepe metinlerinde geçen ekmek çeşitlerinden en iyi tanınanı bappirum $^{56}$ olarak kaydedilen "bira ekmeği"dir. Kültepe tabletleri içerisinde Hititlerde olduğu gibi ekmek üretimine dair detaylı bir kayıt şimdiye kadar ele geçirilmediği için bu konuda bizi daha çok arkeolojik bulgular aydınlatmaktadır. Yine de Hititlerin kendilerinden önceki birçok uygarlıkta olduğu gibi çimlendirilmiş buğday ve arpadan bira ekmeği ürettiği göz önünde bulundurularak, bira ekmeği üretiminde Koloni Çağı insanlarının benzer talimatları izlediği varsayılabilir. Bu doğrultuda bira üretiminde de kullanılan bira ekmeği yapımı talimatnamesinin içeriği şöyledir:

Beslenme Kültürü ve İnsan, (Ankara: İmge Kitapevi, 2020, 162-163.

Albayrak, "Besin Maddeleri”, 60.

48 Epsd

49 CAD A/1, 238.

50 Albayrak, "Besin Maddeleri", 61.

51 Dercksen, "Agriculture in Kaneš", 145.

52 CAD K, 498; CDA, 165; AHw, 500.

53 tahšīmum kelimesi AHw, 1302. sayfada "pasta, hamur işi”" olarak açıklanmıştır.

54 Veysel Donbaz, "Old Assyrian Terms for Bread (akalu, kirrum), H. Behrend, D. Loading, M. Roth (ed.), DUMU.E.DUB.BA.A Studies in Honor of Ake W. Sjöberg, (Philadelphia: University of Pennsylvania Museum, 1989), 91-92.

55 Duymuş Florioti, "Asur Sarayında Beslenme", 31.

56 CAD, 95; CDA B, 38; AHw, 103. 
"Açık renkli, arı ve güzel arpayı al ve onu bir gün boyunca ıslat ve kabarmasını sağla; veya kuytu bir yerde ertesi günün sabahına kadar beklet ve beş saat boyunca tekrar ıslat. Bir kulaç derinliğindeki gözenekli (su sizdıran) bir kaba boşalt ve sürekli nemli tut. Sonra da topak topak oluncaya kadar kurut. Topaklaşma başlar başlamaz onları gevrekleşinceye kadar güneşte kurut; aksi takdirde tadı acı olur. Öğ̈̈t ve tıpkı siradan ekmek hazırlarken yaptığın gibi maya ekleyerek ekmek haline getir. (Bu ekmekleri) fazla yakmadan kizart... "57

Kültepe kazılarında bulunan öğütme taşları tahılların evde işlendiğini gösterirken, ${ }^{58}$ çivi yazılı belgeler bunu desteklemektedir. TC 3, 88 numaralı belgede Anadolu'da öğütme işini kadınların yaptığı anlaşılmaktadır. Belgede evler ve kadın köleler ile birlikte kadın değirmencilerin satılmasından söz edilmektedir (Res 2). ${ }^{59}$

Kültepe kazılarında neredeyse her evde ekmek ve yemek pişirmek için kullanılan firın, ocak ve tandırlara rastlanılması her ailenin kendi ekmeğini ürettiğini göstermektedir (Res. 3) ${ }^{60}$ Akadların tinnиги ${ }^{6 l}$ olarak adlandırdıkları tandır, Anadolu'da M.Ö. 4. binden beri kullanılan en yaygın pişirme öğesidir. ${ }^{62}$ Kültepe'de bulunan tandır örneklerine ek olarak Kıbrıs'ta bulunan ve Metropolitan Müzesi'nde sergilenen tandırda ekmek pişiren kadın heykelciği, ekmek pişirme yöntemlerinin günümüzden farklı olmadığını göstermektedir (Res. 4).

Yerli kadınlarla evli olan Asurlu tüccarların Anadolu'da şehirler arasında sürekli seyahat ettikleri göz önüne alınırsa, ekmek pişirmek kadınların işi olmalıdır. ${ }^{63}$ Kültepe Ib katında bulunan altın damga mühür üzerinde tahtında oturan tanrıça karşısında atlar üzerinde bazlama şeklinde ekmekler görülmektedir. ${ }^{64} \mathrm{Bu}$ küçük ama önemli ayrıntı Kaniš'te tüketilen ekmeklerin şekilleri hakkında bilgi veren nadir örneklerden biridir (Res. 5).

\subsection{Bulgur}

Koloni Dönemi insanları tahılı çeşitli işlemlerden geçirerek yan ürünler elde etmişlerdir. Çivi yazılı metinlerin yanı sıra evlerde bulunan öğütme taşları insanların tahılları öğüterek ihtiyaç duydukları besin maddesine dönüştürdüklerine işaret etmektedir. ${ }^{65}$

Kültepe metinlerinde geçen yan ürünlerden biri olan bulgur "ezmek, kırmak, parçalamak, öğütmek" anlamlarındaki hašāl $u$ fiilinden türetilen hašlātum kelimesi ile ifade edilmiştir. ${ }^{66}$ Kültepe

57 Asuman Albayrak, Ülkü M. Solak ve Ahmet Uhri, Deneysel Bir Arkeoloji Çalışması Olarak Hitit Mutfağ , (İstanbul: Metro Kültür Yayınları, 2008), 169.

58 Özgüç, Asur Ticaret Kolonilerinin Merkezinde Yapılan Yeni Araştırmalar, 25.

59 Öz, Tarım ve Hayvancilı, 47.

60 Özgüç, Asur Ticaret Kolonilerinin Merkezinde Yapılan Yeni Araştırmalar, 40-41.

61 CAD T, 420; CDA, 407.

62 Jean Bottero, "Dünyanın En Eski Mutfağı”, J. Bottero (ed), Eski Yakındoğu Sümer'den Kutsal Kitap'a, (Ankara: Dost Kitapevi, 2005) 70; Ökse," Modern Mutfaklar", 83.

63 Atıc1, "Preliminary Zooarchaeological Evidence", 196.

64 Kutlu Emre, "Hitit Sanatında Kültepe/Kaniş’in İzleri”, F. Kulakoğlu, S. Kangal (ed.), Anadolu’nun Özsözü Kültepe Kaniş-Karumu, (Kayseri: Kayseri Büyükșehir Belediyesi Kültür Yayınları, 2011), 155.

65 Öz, Tarım ve Hayvancllı, 47.

66 Kemal Balkan, "Cancellation of Debts in Cappadocian Tablets from Kültepe", Anatolian Studies Presented to Hans Gustav Gütterbock on the Occasion of his 65th Birthday'den ayr1 basım, (PIHANS), (İstanbul: Nederlands Historisch-Archaeologisch Instituut in het Nabije Oosten, 1974),38; Kılıç, Duymuş, “Anadolu'da Besin Maddeleri”, 343; Esma Öz, "Kültepe Tabletlerinde Geçen hašlātum Kelimesi Üzerine 
tabletleri içerisinde bulgurun yiyecek olarak hazırlanmasıyla ilgili detaylı kayıt bulunmasa da E. Öz, hašlātum'un bazı metinlerde saplarından/kabuklarından ayrılmış/elenmiş hašlātum ifadesi ile geçmesine dayanarak hašlātum'un öğütülüp, haşlandıktan sonra elde edilen bir besin maddesi olduğunu savunmaktadır. ${ }^{67}$

Uzun süre bozulmadan kalabilen bulgur, metinlerden anlaşıldığ üzere karpatum ${ }^{68}$ "toprak kaplarda" ve naruqqum ${ }^{69}$ "çuvallarda" muhafaza edilmiştir. ${ }^{70}$

\subsection{Bira}

Çivi yazılı kaynaklar ve arkeolojik buluntular, fermente bir içecek olan biranın Eski Anadolu insanının sosyal ve dini hayatında önemli bir yer edindiğini göstermektedir. Çağdaş ve rafine bira üretimiyle karşılaştırıldığında, erken Anadolu toplumlarının bira üretim uygulamaları çok basit görünse de bilgi kaynaklarının yeterli olmaması nedeniyle söz konusu toplumlardaki bira üretimi tümüyle anlaşılmamaktadır. A. Ünal'ın tarifine göre bira mayalamak için genellikle şu yöntemler uygulanmıştır:

"Öncelikle arpa, emmer buğdayı ya da darı suya bastırllmış, şişirilmiş ve malt haline getirilmiştir. Tahılın filizlenmesi maltın kurutulmast ya da kavrulması önlenmişstir. Daha sonra kabuklarından ayrılan malt dövülüp, öğütülerek ekşi hamurla yoğrulup bira ekmeği olarak pişirilirdi. Gereksinim ya da olanaklara göre baharat ve diğer katkl maddeleri maya küplerine atılır, küspe mayalanmaya bırakılırdı. Eskiçağ'ın genelinde olduğu gibi eski Anadolu'da da bira üretiminde şerbetçi otu henüz bilinmiyordu". ${ }^{71}$

Mezopotamya' da ana içeceklerden biri olan bira, Kaniš sakinleri tarafından da sık tüketilmiştir. Kültepe metinlerinde bira karşı1lığında šikarum ${ }^{72}$ kelimesi kullanılmışıır. ${ }^{73}$ Bira genellikle masraf listelerinde ve Asurlu tüccarlar arasındaki yazışmalarda arpa, buğday, bira ekmeği (mayası) çimlendirilmiş arpa ve bira kâsesi ile birlikte geçmektedir. ${ }^{74}$ Kültepe tabletlerine göre maya seçimi, fermantasyon süresi ve içeriğindeki ilave maddelere göre eski Anadolu'da birçok bira çeşidi üretiliyordu. Bir masraf listesine ait olan KTH 35 numaralı metinde marnuātum birası, tabalātum birası ve mazītum birası olmak üzere 3 tip bira birlikte kaydedilmiştir. ${ }^{75}$

Kültepe metinleri bira üretimi hakkında uzun ve detaylı tarifler içermese de bazı belgeler bira üretimindeki uygulamalar hakkında bilgi vermektedir. KTH 35 numaralı belgede "9 çuval

Bir Değerlendirme", Tarih Araştırmaları Dergisi, C. 31, S. 51, (2012), 61; Cahit Günbatt1, Kültepe Tabletleri X, (Ankara: Türk Tarih Kurumu, 2016) 42.

67

68

69

70

71

Pulak

$72 \mathrm{CAD} \check{\mathrm{S}} / 2,420$.

73 Michel, "paléo-assyriens", 103.

74 Öz, Tarım ve Hayvancılık, 48.

75 Michel, "paléo-assyriens", 104. 
1 kap aršātum tahılından yarım kap bira maltına dönüştürüldü” ifadesi kaydedilmiştir. ${ }^{76}$ Burada šupaulum "dönüştürmek" fiili ile tahılın malta dönüştürülmesi aşamasından bahsedilmiştir. TC 2, 53 ve BIN 4, 157 numaralı masraf kayıt belgelerinde bira üretiminde kullanılacak yakacak odun fiyatları kaydedilmiştir. Bu aşamada muhtemelen üretilen maltın sslanıp yumuşama süreci hızlandırılmıștır. ${ }^{77}$

Mezopotamya'da olduğu gibi Anadolu'da da bira üretimiyle uğraşan kişiler çoğunlukla Asurlu kadınlar olmuştur. Biracılılıkla uğraşan Asurlu kadınlara ait belgelerde bira üretimi için kullanılacak olan arpa ve mayanın belirli bir kalitede olmasına dikkat ettikleri görülmektedir. Kt n/k 1372 numaralı mektupta Asurlu Akadia "bütün arpayı depo ettim... Bana bira mayası için gönderdiğin arpa iyi değildir, (onu) kullanmayacağım” diyerek tahılın bira üretimi için uygun olmadığını belirtmiştir. ${ }^{78}$ Bira yapımıyla uğraşan başka bir Asurlu kadın olan Tarām-Kūbi, kocası İnnāya'ya yazdığı CCT 3, 25 numaralı mektupta hazırladığı "bira ekmeğinin zamanının geçtiğini" yani ekşidiğini söyleyerek, bira üretiminde kullanılmayacağını belirtmiştir. ${ }^{79}$ CCT 3, 20 numaralı belgede ise Lamassi isimli kadın kocası Pušu-kēn'e yazdığı mektupta "bira mayası hazır ve mükemmeldir" diyerek muhtemelen kaliteli bira hazırlamada kullanabileceğini belirtmiştir. ${ }^{80}$

Düzgün biçimde süzülmemiş ve içinde yüzer madde içeren bira, filtreler takılan kamışlarla tüketilmiştir. Kültepe'de ele geçen bazı mühür baskılarında çömleklerden kamışlarla aynı anda bira içen birkaç kişinin birlikte betimlendiği görülmektedir (Res. 6).

\section{Baklagiller}

Bakliyat grubunu oluşturan besinler en eski dönemlerden itibaren insanoğlunun diyetinde önemli yer edinmiştir. Neolitik Dönem'de kilden çanak çömlek yapımıyla birlikte tahıl ve baklagiller daha kolay pişirilmiş ve insanların günlük menüleri zenginleşmeye başlamıştır. ${ }^{81}$ Günümüzde İç Anadolu Bölgesi'nde nohut, fasulye, mercimek ve hayvan yemi olarak kullanılan fiğ yaygın olarak yetiştirilmesine rağmen Kültepe tabletlerinde baklagillerle ilgili sınırlı bilgi yer almaktadır. ${ }^{82}$ Sözlüklerde "baklagillerden bir bitki olarak" geçen kiššanum'un ${ }^{83}$ hangi bakliyat1 temsil ettiği henüz netlik kazanmamıştır. "A.M. Ulshöfer' in fasulye olarak açıkladı̆̆ kelimeyi, $K$. Balkan mercimek olarak değerlendirmiştir. Kt $\mathrm{g} / \mathrm{k} 18$ numaralı belgede arpa ve bulgur ile 1 çuval kiššanum'un sapların ayrılmış bir ş̧ekilde verildiğinden söz edilmesi, bu kelimenin sözlük anlamının da dikkate alınmasıyla, kiššanum 'un fasulye, bezelye ya da bakla gibi bir sebze olabileceği fikrini kuvvetlendirmektedir". ${ }^{84}$

\footnotetext{
76 Albayrak, "Besin Maddeleri”, 62.

77 Michel, "paléo-assyriens", 98-99.

78 Cahit Günbattı, "Kültepe Tabletlerine Göre, Kadınların Ticari Faaliyetleri Hakkında Gözlemler”, XI. Türk Tarih Kongresi, (Ankara: Türk Tarih Kurumu, 1994), 197.

79 Öz, Tarım ve Hayvancılık, 51.

80 Aliye Kuzuoğlu, “Koloni Çağı'nda Anadolu ve Asur'da Kadın”, Gazi Üniversitesi Sosyal Bilimler Enstitüsü Eskiçağ Tarihi Bilim Dalı, Yüksek Lisans Tezi, Ankara, (2004), 7.

81 Priscilla Mary Işın, Avcllıktan Gurmeliğe Yemeğin Kültürel Tarihi, (İstanbul: Yapı Kredi Yayınları, 2020), 33.

82 Hakkı Yazıcı, İç Anadolu Bölgesi Coğrafyası, Nobel Kitapevi, Ankara 2002, s. 67.

83 CAD K, 456.

84 Balkan, "Cancellation of Debts", 39; Öz, Tarım ve Hayvancllık, 26-27.
} 
C. Günbattı tarafından neşredilen Kt g/k 18 numaralı belgede çeşitli hububatlarla birlikte kiššanum ve apšum kelimeleri de kaydedilmiştir. Kt 97/k 10'da da geçen apšum ${ }^{85}$ kelimesi sözlüklerde "baklagillerden biri” olarak açıklanmıştır. ${ }^{86}$

Kültepe'de yapılan arkeobotanik çalışmalar sonucunda baklagillerden acı fiğ, mercimek ve bezelyenin yaygın olarak tüketildiği görülmüştür. Fiğ, geçmişte sadece hayvan yemi olarak kullanılmış, aynı zamanda insanlar tarafından besin maddesi olarak da tercih edilmiştir. Ancak insanlar tarafından tüketilmeden önce lezzetlendirilmesi gerekmiştir. ${ }^{87}$ Fiğ ile aynı aileden olan acı bakla günümüzde de çerez olarak tüketilmektedir. Acı baklanın yenilebilir hale gelmesi için bir hafta akarsuda ya da her gün tazelenen suda bırakılması gerekir. Daha sonra süzülüp, tuzlanır ve tüketime hazır hale getirilir. ${ }^{88}$

\section{Hayvansal Besinler}

İnsanlar, birincil ürün (et) ve ikincil ürün (hayvansal yağlar, bal, süt) için hayvanlara bağlı olmuşlardır. Kültepe metinlerinde yer alan ifadeler ve arkeolojik buluntular, Kaniš sakinlerinin sofralarında hayvansal besin maddelerine de yer verdiğini göstermektedir. ${ }^{89}$

Orta Anadolu, denize uzak konumu nedeniyle kara toplumu olduğu için denizcilikle ilgili faaliyetlere rastlanılmaz. Ancak bölgede Sakarya Nehri, Kızılırmak ve Yeşilırmak gibi büyük nehirlerin yanı sıra bunların kollarından oluşan pek çok akarsu yer almaktadır. Koloni Dönemi'nde insanların bu kaynakları kullanarak balık temin ettiğine dair dolaylı bilgi veren kaynak sayısı oldukça azdır. Kt 88/k 298 numaralı belgede Pilah-Ǐštar kendisine gönderilen bir takım malzemeler arasında üç adet balık ağını da saymaktadır. Belgede "balık ağı" anlamında kullanılan šěšûm" kelimesi Anadolu insanının balıktan faydalandığına dair önemli bir kanıttır. ${ }^{91}$ Kültepe'nin yakınında yer alan Sarımsaklı Çayı, dönemde balık temini için kullanılan kaynaklardan biri olabilir.

\subsection{Et}

Kültepe tabletlerinde geçen besi hayvanları ve et temini ile ilgili bilgilerin yanı sıra gerçekleştirilen zooarkeolojik çalışmalar, Koloni Dönemi'nde hayvansal gıdanın başında besi hayvanlarının yer aldığını göstermektedir. Zooarkeolojik veriler sonucunda hem Asurlular hem de yerliler arasında koyun, keçi, sığır ve domuzun sıklıkla tüketildiği anlaşılmıştır. Bu hayvanların dışında ciddi oranlarda olmasa da geyik, tavşan, tilki, ördek ve kuş gibi diğer türlerde hayvanlar da tüketilmiştir. ${ }^{92}$

85 CDA, 3.

86 Günbatt1, Kültepe Tabletleri X, 41-43.

87 Fairbairn, "Preliminary Archaeobotanical Investigations", 184-186.

88 Işı, Yemeğin Kültürel Tarihi, 15-16.

89 Atıc1, "Preliminary Zooarchaeological Evidence", 196.

90 CAD $\breve{S} / 2,339$.

91 L. Gürkan Gökçek, “Asur Ticaret Kolonileri Çağı’nda (M.Ö. 1975-1723) Anadolu'da Hayvancılık ve Hayvan Ticareti", Archivum Anatolicum, C.7, S.1, (2004), 75.

92 Atıc1, "Preliminary Zooarchaeological Evidence", 201, tab. 2. 
Hayvan besiciliği çoğunlukla yerli halk tarafından yapılırken, özellikle yerli kadınlarla evli olan tüccarların koyun, sığır ve domuz beslediği bilinmektedir. ${ }^{93}$ Bazı metinlerde geçen alpum mar'um "besili sığır" ifadesinden hayvanların eti ve yağ i için özel olarak beslendiği anlaşılmaktadır. ${ }^{94}$ Besi hayvanlarıyla ilgilenmenin yerli kadınların günlük görevleri arasında olduğunu gösteren TC 2 , 47 numaralı mektupta Aššur-nādā karısı Šišahšušar'a "iyi besili öküzler almasını ve bu hayvanlar için yeterince yem toplamasını" söylemektedir. ${ }^{95}$

Kaniš halkı doğrudan ya da dolaylı yoldan et temin etmiştir. Kültepe metinlerinde koyun, keçi, sığır ve domuz gibi hayvanların sayısı ile ilgili çok sayıda belge vardır. Satın alınan bu hayvanlar istenilen besiye ulaşınca muhtemelen evlerde kesilmiştir. Metinlerde širum "et" ya da bušălum "kızartılmış et" satın alınmasıyla ilgili kayıtlar mevcuttur. ${ }^{96}$ Ancak bu etin satıcısı belirtilmediği gibi Kültepe'deki herhangi bir metinde țābihum ${ }^{97}$ "kasap" kelimesine rastlanılmamıştır. ${ }^{98}$ Buna rağmen bazı metinlerde, irtum "göğüs eti", karšum "işkembe" (belki sakatat), arkātum "but eti", ve kursinnum "incik" gibi kesilen hayvanın etinin, hayvanın hangi bölgesine ait olduğuna dair bilgilere yer verilmiştir. ${ }^{99}$ TC 1, 19 numaralı metinde geçen "bana bir kasap bıçağı gönder" ifadesi insanların hayvanları kendilerinin kestiğini düşündürmektedir. ${ }^{100}$

Kültepe'de bulunan hayvan kemikleri üzerinde yapılan zooarkeolojik incelemeler sayesinde hayvanların tüketilirken hangi işlemlerden geçirildiği anlaşılmaktadır. Bazı hayvan kemikleri üzerinde kesi izlerine rastlanılması daha uzun boyutlardaki kemiklerin kolay tüketilmesi için küçük boyutlara getirildiğini göstermektedir. Ayrıca kemik üzerindeki et, tamamen sıyrıldıktan sonra kemik içerisindeki iliğin çıkarıldığına dair izler mevcuttur. ${ }^{101}$

En erken çağlardan itibaren insanoğlunun beslenme alışkanlığında önemli yer tutan et ürünlerinin tüketiminde Kaniš halkının hangi pişirme yöntemlerini kullandıklarına dair bilgiler tabletlerde mevcuttur. Metinlerde geçen bušālum "kızartılmış et" ve silqum "haşlanmış et" terimleri et ürünlerinin çoğunlukla ateşte ve suda haşlama yöntemleriyle pişirildiğini göstermektedir. Bu yöntemlerin dışında daha uzun vadede tüketilmesi planlanan etler tuzlanıp, kurutularak muhafaza edilmiştir. ${ }^{102}$ Zamanlarının çoğunu ticari faaliyetleri doğrultusunda kentler arasındaki kervan yollarında geçiren tüccarlara ait masraf kayıt belgelerinde konaklama ve yeme-içme ihtiyaçlarını gidermek için bït wabrim "han, kervansaray" 103 tercih edildiği anlaşılsa da bu imkânın bulunmadığ bölgelerde tüccarlar aç kalmamak için yanlarına çabuk bozulmayan kurutulmuş etler ve konserve

93 J. Gerrit Dercksen, "Subsistence, Surplus and the Market for Grain and Meat at Ancient Kanesh", Altoriental Forsch, C. 3, S. 1, (2009), 94.

94 Albayrak, "Besin Maddeleri”, 63.

95 Michel, "Kaniş’in Kadınları", 131; M. Trolle Larsen, The Aššur-nādā Archive, (Leiden: Nederlands Instituut Voor Het Nabije Oosten 2002), 75-76.

96 Albayrak, "Besin Maddeleri", 63.

97 CAD Ț, 6.

98 Dercksen, "Grain and Meat at Ancient Kanesh", 94, 96.

99 Albayrak, "Besin Maddeleri”, 63; Atıc1, "Secondary Products”, 243.

100 Michel, "paléo-assyriens", 99.

101 At1c1, "Preliminary Zooarchaeological Evidence", 200, 203.

102 Et, balık vb. besinlerin tuzlanarak muhafaza edilmesi sözlüklerde midlu kelimesi ile karşılanmıştır. Bkz. CAD M/2, 48; Michel, "paléo-assyriens", 110; Duymuş Florioti, "Asur Sarayında Beslenme", 33.

103 Larsen, City-State and its Colonies, 279. 
yiyecekler almış olmalıdır. ${ }^{104}$

Günümüz sofralarında da yer verdiğimiz haşlama için Kaniš halkı iliğin bol bulunduğu kemikleri kullanmış olabilir. Nitekim zooarkeolojik veriler uzun kemiklerin daha kolay pişirilmesi için belki de yemeğin pişirileceği tencereye daha kolay sığması için ufak parçalarda kesildiğine işaret etmektedir. ${ }^{105}$ Hatta bu sulu yemeğin lezzetini artırmak için içerisine çeşitli sebzeler eklenmiş olabilir.

Kizartılmış et olarak kaydedilen bušālum'un pişirilme yöntemi hakkında herhangi bir bilgi yer almaz. Ancak pratik bir yöntem olarak etler şişe takılarak pişirilmiş olabilir. ${ }^{106}$ Kızartılan bu etler muhtemelen Hititlerde olduğu gibi ekmek arasında hazırlanan sandviç gibi tüketilmiştir. ${ }^{107}$

Yemek hazırlanırken etin lezzetini artırmak için Kültepe metinlerinde kaydedilmiş baharatların yanı sıra zeytinyağı, bal ve şarap kullanılarak hazırlanan çeşitli soslar eklenmiş olmalıdır. ${ }^{108}$

\subsection{Hayvansal Yağlar}

Kültepe metinleri içerisinde Koloni Dönemi’nde Kaniš sakinleri tarafından domuz yağ1 ve tereyağı kullanımına ait kayıtlar mevcuttur. Metinlerde İ.ŠAH (ša huzīrim) ve Ì.Gİš ša huzīrim olarak geçen domuz yağı, Anadolu'da sık tüketilen hayvansal yağlardan biri olmuştur. ${ }^{109}$

Asurlu tüccar Aššur-muttabil' in eşi Kunnanīya’ya gönderdiği mektupta geçen “eğer domuzlar şişmanlamaz, yağlanmazsa, sat onlart. Besili yağlı olurlarsa elde kalsinlar"110 ifadesinden domuzların etlerinin yanı sıra özellikle yağları için beslendiği anlaşılmaktadır. Kültepe metinleri içerisinde domuz yağının besin maddesi olarak nasıl tüketildiğine dair bilgi bulunmamaktadır. Aššur-nādā'nın eşi Šišahšušar'a yazdığı mektupta “deri kap içerisindeki 55 mina (yaklaşık 27,5 kg) katı (sert) domuz yă̆ı" ifadesinden yola çıkarak domuz yağının tüketime kadar nasıl muhafaza edildiği hakkında fikir sahibi olabiliriz. ${ }^{111}$ Hayvanın kesiminden sonra elde edilen iç yağı kolaylıkla eritilerek deri kaplar içerisinde saklanarak kullanıma kadar muhafaza edilmiş olabilir. Doymuş yağ oranı oldukça düşük olan domuz yağı bu özelliği sayesinde uzun süre saklanabilir.

Eski Anadolu mutfaklarında kullanıldığı bilinen hayvansal yağlardan bir diğeri de tereyağıdır. Kültepe tabletlerinde Akadca himētum ${ }^{112}$ yazılışı ile görülen tereyağı ile "deri, torba" anlamına gelen himtum ${ }^{113}$ kelimesinin ilişkili olabileceği düşünülmektedir. ${ }^{114}$ Anadolu sofralarının en sık kullanılan yağ çeşitlerinden olan tereyağı uzun yıllar boyunca geleneksel yöntemlerle muhafaza edilmiştir. Kurutulmuş koyun ve keçi işkembesine doldurulan tereyağı tüm kış boyunca bozulmadan

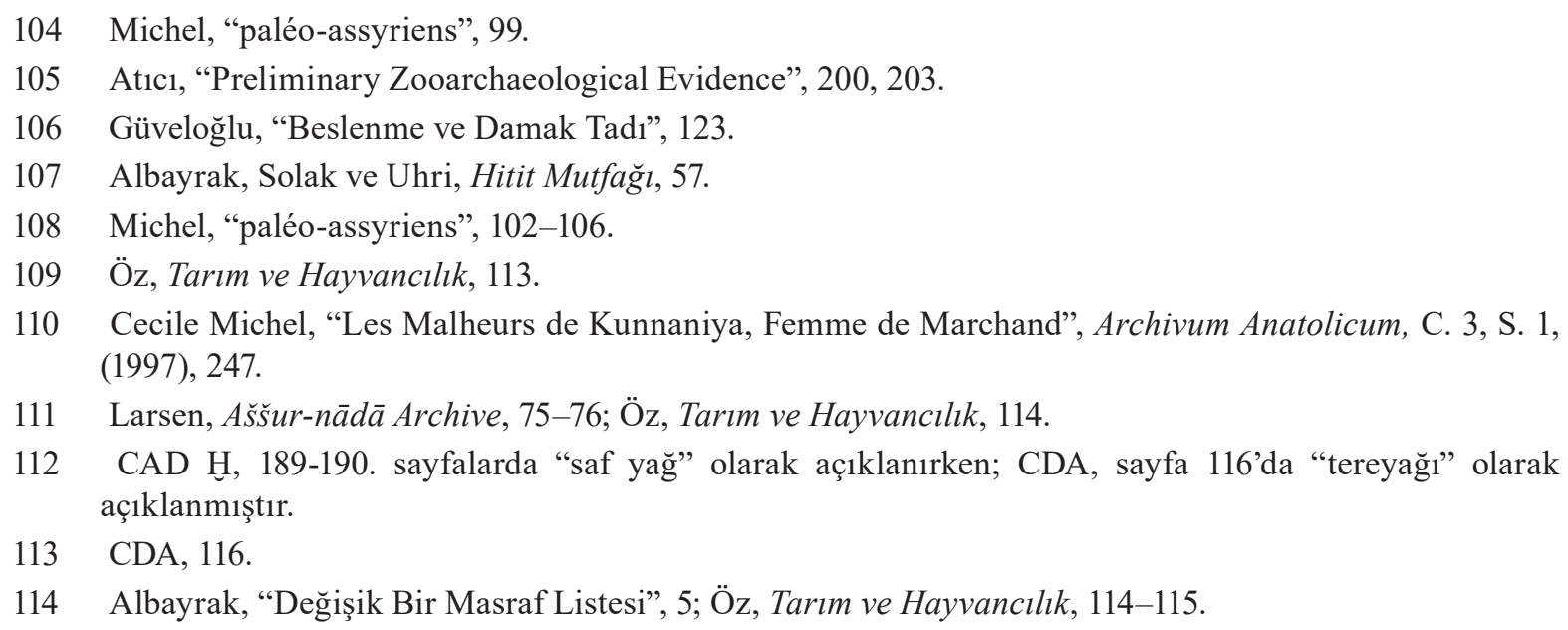


saklanmıştır. Metinde tereyağı ile ilişkili olabileceği düşünülen himtum ile belki de tereyağın muhafaza ediliş yöntemine değinilmiş olabilir. ${ }^{115}$

\subsection{Süt ve Süt Ürünleri}

Büyükbaş ve küçükbaş hayvanlar insanların et, post ve kemik gibi birincil ürün ihtiyaçlarını karşılarken aynı zamanda yün ve süt elde etmede ve eğer büyükbaş hayvansa çift sürme ve taşımada kullanılmıștır. ${ }^{116}$

Kültepe metinleri ve arkeolojik buluntular bu dönemde hayvancılığın yaygın olarak yapıldığını gösterse de belgelerde šizbum"117 "süt” ve sağım eylemini içeren ifadelere rastlanılmamıştır. Bu durum Koloni Çağı'nda süt ve süt ürünlerini bilmediği şeklinde yorumlanmamalıdır. ${ }^{118}$ Süt ve sütten elde edilen besinler kolay bozulabilir olduğu için nakliyesi ve uzun süre muhafaza edilmesi kolay değildir. Bu nedenle ticareti yapılmayan bu ürünlere çoğunluğu maddi kayıtlar içeren Kültepe tabletlerinde yer verilmemiştir. Metinlerde geçtiği bilinen tek süt ürünü, ticaretinin de yapıldı̆̆ bilinen tereyağı olmuştur. ${ }^{119}$

Anadolu'nun kırsal bölgelerinde çiftlik hayvanlarının bakımı, süt sağma ve süt ürünleri üretimi gibi faaliyetler kadınların günlük işlerinin bir parçasıdır. ${ }^{120}$ Kültepe metinleri içerisinde de besi hayvanlarının günlük bakımlarının kadınlar tarafından yapıldığına dair kayıtlar mevcuttur. ${ }^{121}$ Bu durumda hem Asurlu hem de yerli ailelerin sofralarında yer alan süt ve süt ürünleri muhtemelen evlerde kadınlar tarafından üretilip, hane halkının tüketimine sunulmuş olmalıdır.

M.Ö. 2500 yılına tarihlenen bir taş kabartma Mezopotamya'daki süt kullanımının erken dönemlerden itibaren başladığını kanıtlamaktadır. Kabartmada yer alan ineklerin sağımı, sağılan sütün tulumda biriktirilip süzülmesi ve sütten elde edilecek ürünün saklanmasında kullanılacak olan amforanın temizlenmesini gösteren sahneler Sumerlilerin süt teknolojisini iyi bildiğini göstermektedir (Res. 7). ${ }^{122}$ Anadolu' da ise Batı Anadolu'daki Ulucak ve Barçın Höyük ile Orta Anadolu'daki Çatalhöyük kazılarında bulunan çanak çömlekler üzerinde karbon izotop incelemeleri süt ürünlerinin Neolitik Dönem'den itibaren insanların besin diyetinde yer aldığını göstermektedir. ${ }^{123}$ Hitit metinlerinde GA ideogramı ile gösterilen süte ilaveten GA.KIN.AG ile gösterilen peynirin ve GA.KALA.GA ile gösterilen ve koyun sütü ile yoğurt (?) anlamına gelen sözcüklerin çıkması, Hititlerin bazı fermantatif yöntemlerle sütten değişik ürünleri elde ettiğini gösteren kayıtlar olarak kabul edilebilir. ${ }^{124}$

\footnotetext{
115 Işın, Yemeğin Kültürel Tarihi, 96-97.

116 Uhri, Mutfak Kültürünün Kökenleri, 77.

117 CAD Š/3, 148; CDA, 378.

118 Albayrak, "Besin Maddeleri”, 65; Atıc1, "Secondary Products, 246.

119 Atıc1, "Secondary Products, 247.

120 Jak Yakar, Eski Anadolu Toplumunun Arkeolojideki Yansımaları I, (İstanbul: Homer Kitapevi, 2014), 196.

121 Michel, "Kaniş’in Kadınları", 131; Larsen, Ǎš̌ur-nādā Archive, 73-83.

122 Henri Limet, "The Cuisine of Ancient Sumer", The Biblical Archaeologist, C. 50, S. 3, (1987), 135-136.

123 Uhri, Mutfak Kültürünün Kökenleri, 182.

124 Sedat Alp, Hitit Güneşi, (Ankara: Tübitak Yayınları, 2003), 47; Albayrak, Solak ve Uhri, Hitit Mutfăğl, 77.
} 
Hayvanlardan elde edilen sütler çeşitli şekilde işlenerek peynir, yoğurt ve tereyağı üretiminde kullanılmış olmalıdır. Kültepe metinlerinde himētum "tereyağg" ifadesinin geçmesi, dönemde sütün işlenebilirliğini göstermesi açısından önemlidir. ${ }^{125}$ Bilindiği gibi tereyağı, ya çiğ süt ya da yoğurdun uzun süre çalkalanmasıyla elde edilmektedir. Bu dönemde tereyağı üretiminde hem süt hem de yoğurt kullanılmış olabilir. Kültepe kazılarında yayık kullanımına dair henüz bir arkeolojik kanıt bulunamamıştır. Ancak Kt 87/k 386 numaralı metinde šakirrum ${ }^{126}$ olarak adlandırılan ve sözlüklerde "yayık” şeklinde tanımı yapılan bir kap ismi ile karşılaşılmıştır. ${ }^{127}$

Etnoarkeolojik verilen Anadolu'nun birçok yerinde halen yoğurt üretimi için sütün meşe palamudu ile mayalandığını göstermektedir. ${ }^{128}$ Kültepe metinlerinde allānum olarak geçen meşe palamudu yoğurt yapımı için kullanılmış olabilir.

Çanak çömlek üzerinde yapılan biyokimyasal ve izotop incelemelerine ilaveten kapların formları süt ve süt ürünlerinin tüketimi kanıtlanabilir. ${ }^{129}$ Sıvı bir maddenin çökeltisini toplamak için kullanılan süzgeçli kaplar bugün halen süt ürünleri üretiminde geleneksel bir yöntem olarak Anadolu'da kullanılmaktadır. ${ }^{130}$ Süzgeç şeklindeki bu kap formunun örneğine Kültepe'nin II. yap1 katında rastlanılmıştır (Res. 8). ${ }^{131} \mathrm{Bu}$ formdaki kap peynir üretiminde tortu süzmek için kullanılmış olabilir. Kültepe'de bulunan çanak çömleğin zenginliğine rağmen henüz süt ve süt ürünleri tüketimini aydınlatacak detaylı bilgi mevcut değildir. Ancak yapılacak yeni çalışmalarla bu konuda daha fazla bilgi edilmesi muhtemeldir.

\subsection{Bal}

Başlangıçta meyve kuruları ve bal ile karşılandığı düşünülen şeker gereksinimi, olasılıkla içgüdüsel olarak çok eski çağlardan beri insanoğlunun beslenmesinde önemli yer tutmuş olmalıdır. ${ }^{132}$

Kültepe tabletlerinde Akadca dišpum ${ }^{133}$, Sumerce LÀL yazılışlarıyla geçen bal, M.Ö. II. binde Anadolu'da bilinen bir besin maddesiydi. ${ }^{134}$ Albayrak, BIN 6, 29 numaralı metinde geçen LÀL šaqû "içilecek bal" ifadesi ile bala sıvı katılarak şurup haline getirilen bir içecekten bahsedilmiş olunabileceğini belirtmektedir. ${ }^{135}$ Öz, bu karışımın şarap ya da pekmez yapımında tatlandırıcı olarak kullanılmış olma ihtimalini dile getirmektedir. ${ }^{136}$ Hititçe metinlerde geçen GEŠTIN. LÀL "ballı şarap" terimi şarap üretiminde balın kullanıldığını gösterir. Ayrıca Hitit metinlerinde geçen

125 Albayrak, "Değişik Bir Masraf Listesi", 5; Öz, Tarım ve Hayvancllık, 114.

126 CAD Š/1, 167; CDA, 349.

127 Gökçek, "Kültepe Metinlerinde Geçen Kaplar", 85.

128 Uhri, Mutfak Kültürünün Kökenleri, 73.

129 Jean Denis Vigne, Daniel Helmer, "Was Milk a "Secondary Product" in the Old World Neolithisation Process? Its Role in the Domestication of Cattle, Sheep and Goats", Anthropozoologica, C. 42, S. 2, (2007), 13.

130 Uhri, Mutfak Kültürünün Kökenleri, 79.

131 Özgüç, Kültepe Kaniš/Neša, 148 dp. 163.

132 Uhri, Mutfak Kültürünün Kökenleri, 46.

133 CAD D, 161.

134 Öz, Tarım ve Hayvancilı, 110.

135 Albayrak, "Besin Maddeleri”, 65.

136 Öz, Tarım ve Hayvancılık, 110. 
NiNDA. LÀL "ballı ekmek" ya da "tatlı ekmek" ifadesi balın ekmeği tatlıya dönüştürmede de kullanıldığını göstermektedir. ${ }^{137}$

Yakın zamanda yayınlanan bir Kültepe tabletinde geçen aluwarum kelimesinin bal ile ilişkili olup olmadığı henüz bilinmese de, tatlı bir besin olduğu anlaşılan aluwarum ile ilgili metnin tercümesinin bu kısımda aktarılması uygun bulunmuştur. Šu-İštar'ın oğlu İlīi-imittī tarafindan Kururuya'ya hitaben yazılan bir mektupta anlamın bilmediğimiz aluwarum temini ile ilgili şu talimatlar verilmektedir: "Kururuya'ya söyle! İlīimitț̄ şöyle (söyler): Sen kardeşimsin, burada sen de gördün ki aluwarum tatll (idi) Sen kardeşimsin; eğer beni seviyorsan orada, bunun gibi kaliteli aluwarum 'u çağır (/borç al ?), tatlı (olsun); buraya getir'. Metinde geçen aluwarum 'a sözlüklerde rastlanılmazken, H. Erol, bu kelimenin țābum "tatlı" sıfatılla nitelendirilmiş olmasından dolayı yerel dillerde bir yiyecek ya da içecek olabileceğini belirtmektedir. ${ }^{138}$

\section{Sebze ve Meyve Tüketimi}

Arkeobotanik ve etnoarkeolojik veriler Anadolu'nun farklı bölgelerinde dut, fistık, badem, alıç, yabani erik, incir gibi değiş̧ik meyvelerin yanı sıra özellikle Neolitik Dönem sonrasında armut, kayısı ve elma meyvelerinin florada yer aldığını göstermektedir. Bütün bu meyvelere ek olarak soğan ve sarımsak gibi sebzelerle çeşitli yenilebilir otların kurutulma işlemi yapılarak saklandığı düşünülebilir. Sözlüklerde "kurutulmuş meyve dizisi" şeklinde açıklanan šerku' ${ }^{139}$ kelimesi başta elma ve incir olmak üzere hemen bütün meyvelerin kurutulmuş hallerini ifade etmek için kullanılmıştır. ${ }^{140} \mathrm{Bu}$ ifade günümüzde kışın tüketilmek için bazı meyve ve sebzelerin ipe dizilerek kurutulması işleminin oldukça eskiye dayandığını göstermektedir. Anadolu'nun birçok yerinde halen kışa hazırlık için biber, patlıcan, kabak gibi sebzelerin yanında başta kayısı, incir ve üzüm olmak üzere elma, armut, erik gibi meyveler kurutularak muhafaza edilmektedir.

Koloni Dönemi Anadolu'sunda sebze ve meyvelerin iki farklı şekilde tüketildiği varsayılabilir. Mevsiminde taze olarak tüketilen meyve ve sebzeler, kış aylarında kullanılmak üzere kurutularak muhafaza edilmiş olmalıdır.

Kültepe metinlerinde meyvelerin aksine nadir olarak rastlanılan sebze isimleri tam olarak açıklanamadığı için bu bitkilerin çoğunun karşılığı henüz bulunamamıştır. ${ }^{141}$ Ancak son yıllarda Kültepe'de gerçekleştirilen arkeobotanik ve paleobotanik çalışmalar sebze-meyve tüketiminin daha iyi anlaşılmasına yardımcı olmuştur. ${ }^{142}$

Orta Anadolu'nun iklimi soğan yetiştiriciliği için elverişli olduğu için Koloni Dönemi'nde muhtemelen yeşil soğan, kuru soğan ve yabani soğan gibi birçok soğan türü yetiştirilebiliyordu. ${ }^{143}$ Tüm Yakındoğu'da iyi bilinen ve çokça tüketilen soğan, Kültepe metinlerinde šumkü ${ }^{144}$ kelimesi ile geçmektedir. ${ }^{145}$ Soğan belgelerde çoğunlukla başka besinler ve yemek yapımında kullanılan

137 Albayrak, Solak ve Uhri, Hitit Mutfa $\breve{g}$, 82-83.

138 Hakan Erol, Kültepe Tabletleri XI-a, (Ankara: Türk Tarih Kurumu, 2018), 200-201.

139 CAD $\breve{S} / 2,316$.

140 Uhri, Mutfak Kültürünün Kökenleri, 43.

141 Michel, "paléo-assyriens", 107.

142 Fairbairn, "Preliminary Archaeobotanical Investigations", 177.

143 Öz, Tarım ve Hayvancilık, 26.

$144 \mathrm{CAD} \breve{S} / 3,274$.

145 Veysel Donbaz, "One 1-B Kültepe Text Concerning Onions", ”, H. Klengel and J. Renger (ed.), 
malzemelerle birlikte anılmıştır. Örneğin Ennam-Aššur isimli tüccarın Nabid-Enlil'e hitaben yazdığı bir mektupta soğan ile birlikte šuhatinnū adında başka bir bitki daha geçmektedir. ${ }^{146}$ Hangi sebzeye karşılık geldiği bilinmeyen bu sözlüklerde "bir soğan çeşidi" 147 şeklinde açıklandığ gibi "soğan gibi kokulu bir bitki" 148 olarak tanımlanarak akla sarımsak olabileceğini de getirmektedir.

İ. Albayrak tarafından neşredilen ve Kültepe'de Koloni Çă̆ı insanlarının mutfak ve beslenme alışkanlıkları hakkında önemli bilgiler içeren Kt 88/k 71 numaralı belgede soğan beraberinde ekmek, et, bira maltı, şarap, yağ, bal, bulgur, arpa ve yemek yapımında kullanılan farklı boyutlardaki kazanlar ve odun ile birlikte anılmıştır. ${ }^{149}$

Soğan ve sarımsak metinlerde geçse de, makrofosil topluluğuna dâhil olduklarından Kültepe'deki arkeobotanik çalışmalarda izlerine rastlanılmamıştır. ${ }^{150}$

Kültepe'de bulunan bitki kalıntıları üzerinde yapılan arkeobotanik çalışmalar neticesinde incelenen örnekler arasında tohum ve meyvelerin yanı sıra kömürleşmiş doku örneklerine de rastlanılmıştır. Kömürleşmiş dokular üzerinde yapılan detaylı çalışma bu örneklerin yumru bitkiler ve bir çeşit yenilebilir yapraklı bitkiye ait olduğunu göstermektedir. ${ }^{151}$ Anadolu'da günümüzde yetiştirilen başlıca yumru bitkiler patates, havuç, soğan, sarımsak, turp, kereviz, pancar ve yer elmasıdır. Kültepe'de bulunan yumru bitki kalıntılarının makrofosil topluluğuna dâhil olduklarından tespiti yapılamadığı için soğan ve sarımsağa ait olmadığı kabul edilebilir. Bu durumda Anadolu'da ekimi en yaygın olan yumru bitki olan patates akla gelebilir. Ancak ana vatanı Güney Amerika olan patates önce 16. yüzyılda Avrupa'ya, 20. yüzyılda ise Anadolu'ya getirilmiştir. ${ }^{152} \mathrm{Bu}$ durumda Koloni Çağı insanlarının mutfağında patatesin yer almadığını söyleyebiliriz. Günümüzde Anadolu mutfağının vazgeçilmez tatlarından biri olan domates, Güney Amerika kökenli olup, patates gibi Anadolu’ya geç dönemlerde getirildiği için Koloni Dönemi mutfaklarında yer almamıştır. ${ }^{153}$

Kültepe metinleri ve arkeobotanik veriler içinde yenilebilir otlarla ilgili bilgi yok denecek kadar azdır. Buna karşın Hitit metinlerinde çok sayıda çiçek ve otsu bitkinin adı kullanım alanları

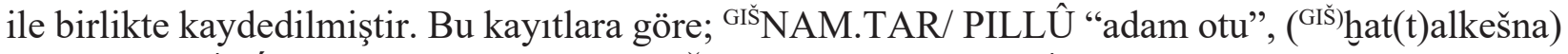
"ak diken", UGÍR.TAB "akrep otu”, BU'ŠANU "aksırı otu”, ÚIMHUURLIMU "aygün çiçeği”, ZAG.AH.LI "ayrık otu”, ŠAKIRU "banotu”, Gišalanza(n) "defne", NA-A-RUŠAR "dere otu”, ÚSILÀ "gül”, ŠÛŠu "meyan kökü", SIHUU "miskotu", URNÛ "nane" gibi bilinen birçok bitki farklı alanlarda kullanılmıştır. ${ }^{154}$ Zengin bir floraya sahip olan Anadolu'da, halk mutfağında oldukça

Landwirtschaft im Alten Orient. Ausgewählte Vorträge der XLI. Rencontre Assyriologique Internationale (CRRAI 41), (Berlin: Dietrich Reimer Verlag, 1994), 149-150.

146 Albayrak, "Besin Maddeleri”, 64.

147 CDA, 380.

$148 \mathrm{CAD} \breve{S} / 3,316$.

149 Albayrak, "Masraf Listesi”, 1-10.

150 Donbaz, "Onions", 149; Fairbairn, "Preliminary Archaeobotanical Investigations", 184.

151 Fairbairn, "Preliminary Archaeobotanical Investigations", 189.

152 Linda Civitello, Mutfak ve Kültür Insanın Beslenme Tarihi, (Ankara: Bilim ve Sanat Yayınları, 2019), 180-109.

153 Kazım Abak, “Türkiye’de Domatesin Dünü, Bugünü ve Yarını”, Türkiye Tohumcular Birliği Dergisi, C. 5, S. 17, (2016), 8.

154 Hitit Dönemi Anadolu'sunun Florası için bkz. Hayri Ertem, Boğazköy Metinlerine Göre Hititler Devri Anadolu'sunun Florası, (Ankara: Türk Tarih Kurumu, 1987) 
popüler olan ve çeşitli şekillerde tüketilen bazı otların (gelin parmağı, efelik, 1sırgan, madımak, yemlik, çiriş otu gibi) Koloni Dönemi’nde insanlar tarafından tanınıp tanınmadığı bilinmemektedir.

Hititçe çivi yazılı metinlerin verdiği bilgiye göre Eski Anadolu'da, fasulye, bezelye, pancar, pırasa, salatalık, sarımsak, dereotu gibi sebze çeşitleri de biliniyordu. ${ }^{155}$

Çivi yazılı belgelerle birlikte arkeolojik buluntular Koloni Çağı'nda insanların bazı meyveleri tanıdığına işaret etmektedir. Kültepe kazılarında farklı formlarda ele geçirilen meyvelikler, Kaniš’te en çok kullanılan kaplardan biri olmuştur. ${ }^{156}$ Kültepe tabletlerinde sık rastlanılan meyve isimlerinden biri olan üzüm, yetiştiriciliği yapılan ve tüketilen meyveler arasında ilk sırada yer almaktadır. Metinlerde ka/irānum ${ }^{157}$ olarak geçen üzüm, mevsimine göre yaş ve kuru olarak tüketilmesinin yanı sıra birtakım işlemlerden geçirildikten sonra şarap olarak da tüketilmiştir.

"Şarap, Eski Anadolu insanı için sıradan bir içecek olmamıştır. Bir metinde kayıtll GAL karānim "şarap (üretiminden sorumlu kişilerin) amiri”" unvanı, şarabın hazırlanması ve sunulması gibi birtakım işlemlerden sorumlu kişilerin olduğunu ve bunun bir meslek olarak yapıldığını göstermektedir ki, bu durum şaraba verilen önemin bir işaretidir. Muhtemelen bu kişiler, kral yemeklerinde veya tanrlar için yapılan bayram törenlerinde şarap sunan ve sarayın ihtiyacı olan şarabın hazırlanmasından sorumlu olan kişilerdi". ${ }^{158}$

Şarap bazı Hitit yemeklerinde lezzet artırıcı olarak kullanılmıştır. Özellikle etin pişirilmeden önce terbiye edilmesi ve yumuşaması için şarapta bekletildiği tahmin edilmektedir. ${ }^{159}$ Koloni Dönemi'nde de yaygın olarak tüketilen et pişirilmeden önce benzer bir işleme tabi tutulmuş olabilir.

Kültepe metinlerinde çok sık olmasa da geçen tittum "incir" ve lurmum "nar" meyveleri bu dönemde nar ve incirin tanındığını göstermektedir. ${ }^{160}$

Sözlüklerde "meşe palamudu" olarak açıklanan allānū $m^{161}$ Kaniš sakinleri tarafından tanınıp, tüketiliyordu. Meşe palamudunun birçok türü günümüzde Anadolu'da çeşitli yöntemlerle yemiş olarak tüketilmeye devam etmektedir. Meşe palamudunun acı türleri toprağa gömülerek ya da küllerin üzerinde kavrularak tüketildiği gibi acı olmayan türleri hiçbir işleme tabi tutulmadan çiğ halde yenilmektedir. ${ }^{162}$ Meşe palamudunun Eski Anadolu'da mayalama işlemi için kullanıldığına dahaönce değinmiştir ancak Kaniš’ te bu amaçla kullanıldığına dair bir kanıta henüz rastlanılmamıştır.

C. Michel'in meşe palamudu dışında yenilebilir kabuklu bir yemiş olarak tanımlandığı allānūm ile ilgili yeni öneriler bulunmaktadır. ${ }^{163} \mathrm{~T}$. Sturm, allānūm kelimesinin findık anlamına gelebileceğini önermektedir. ${ }^{164}$

155 Kilıç, Duymuş, “Anadolu'da Besin Maddeleri”, 344.

156 Özgüç, Kaniš/Neša, 118.

157 karānum/kirānum sözlüklerde "üzüm” olarak tanımlandığı gibi aynı zamanda "şarap" olarak da açıklanmıştır. CAD K, 202; CDA, 148.

158 Esma Öz, "Kültepe Tabletlerine Göre Asur Ticaret Kolonileri Döneminde Anadolu'da Üzüm Yetiştiriciliği ve Bağcılık", Gazi Akademik Bakış, C. 5, S. 9, (2011), 286-287.

159 Albayrak, Solak ve Uhri, Hitit Mutfă̆, 183.

160 Öz, Tarım ve Hayvancllık, 34-37.

161 CAD A/1, 354; CDA, 12.

162 Işın, Yemeğin Kültürel Tarihi, 16.

163 Michel, "paléo-assyriens”, 107.

164 Thomas Sturm, "allānū- Haselnüsse als Delikatesse im kārum-zeit/ichen Handel von Anatolien nach 
Kültepe'de gerçekleştirilen arkeobotanik çalışmalara kadar fındığın burada tanındığı ve tüketildiğine dair bir kanıt yoktu. Kültepe'de Orta Tunç Çağı'na ait kömürleşmiş örnekler içerisinde findığın kabuklu haline rastlanılmasıyla metinlerde varlığı henüz netlik kazanmayan findığın tüketildiği kanıtlanmıştır. Arkeobotanik buluntular allānūm'un fındık olduğunu kanıtlayamasa da Kaniš’te fındığın tanınıp, tüketildiğini kanıtlamaktadır. Kayseri ve çevresindeki bölgelerin doğal florasına ait olmayan findık, muhtemelen Karadeniz kıyılarındaki dağlık bölgelerden temin edilmiştir. Kültepe metinleri içerisinde Karadeniz Bölgesi'nde olduğu varsayılan önemli bir bakır pazarı olan Durhumit de dâhil olmak üzere bu bölge ile ticari ilişkilerin olduğunu gösteren kayıtlar mevcuttur. Fındığın bu ticaret vasıtasıyla Kaniš'e getirildiği düşünülmektedir. Kullanım alanı tam olarak bilinmeyen fındığın Nimrud'daki arkeolojik buluntuları M.Ö. 1. binden itibaren keklerde kullanıldığını göstermektedir. ${ }^{165}$

Koloni Dönemi'nde yemeğin daha kolay pişmesi ve daha lezzetli olması için hayvansal yağlarla birlikte bitkisel yağların da kullanıldığı bilinmektedir. Metinlerde Akadca šamnum, Sumerce Ì.GIŠ olarak geçen yă̆, çoğunlukla susam ve zeytinden elde edilmiştir. Kültepe metinlerinde geçen ifadelere göre yağlar üretim kalitesine göre šamnum "normal"166 , tâbum "ince (iyi)", rēštûm "birinci kalite" ve marrurum "acı" olmak üzere farklı şekillerde sınıflandırılmıştır. ${ }^{167}$ Kt 92/k 327 numaralı belgede Šu-Ǐštar'ın eşi Haditum ve temsilcilerinden biri olan Adadaya'nın satın aldıkları kaliteli yağ şu şekilde konu edilmiştir: "Bize yazdı̆̆ın çok kaliteli 1BANEŠ (30 litre) yă̆ hakkında; sen şöyle (demiştin): "Adadaya ve Haditum gümüşünü verdikleri çok kaliteli 1BANEŠ yağı aldılar mı?” Burada ikisine sordum ve onlar şöyle (söylediler): "Çok kaliteli 25 SILA (25 litre) yă̆l aldık”. ${ }^{168}$

Yıldırım, Kültepe metinlerinde Ì.GĭŠ “yă̆" ile birlikte geçen dulbātum kelimesinin bazı belgelerde litre ile birlikte kaydedilmiş olmasından yola çıkarak, dulbātum'un sıvı maddeler ve yağların muhafazasında kullanılan bir tür saklama kabı olabileceğini belirtmektedir. ${ }^{169}$

\section{Tuz ve Baharat Kullanımı}

İnsanoğlunun dünya üzerinde varlığını sürdürebilmesi için su, oksijen ve enerjiden sonra ihtiyaç duyduğu bir diğer madde turdur. Tuz, vücudun elektrolit dengesini korumak için diğer mineraller kadarönem taşımaktadır. Tuzsuzluk sonuç olarak ölüme kadar götüren bazı rahatsızlıklara sebep olsa da, bu süreçte hiçbir zaman tuz isteği susuzluk ya da açlık gibi ortaya çıkmaz. İnsanoğlu hayvansal ürünlerle birlikte bitkisel ürünleri de besin menüsüne eklemeye başladığında tuzun pişirmede aynı ateş gibi bir etkisinin olduğunu fark etmiştir. İnsanlar tuza yatırılan besinlerin kuruyarak dayanıklı hale gelmesini keşfetmiştir. Çürüme ve mayalanmanın insan denetimi altında gerçekleşerek farklı tatlarda ürünler ortaya çıkarması, tuzun dönüştürücü özelliğinin keşfedilmesini sağlamış ve erken dönemlerden itibaren tuzu vazgeçilmez bir besin haline getirmiştir. ${ }^{170}$

Nordmesopotamien (ca 1930-1730 v. Chr.)", Altorient Forsch, C. 35, (2008), 296 vd.

165 Fairbairn, Kulakoğlu ve Atıcı, "Hazelnut", 72.

166 Albayrak, "Besin Maddeleri”, 62.

167 Michel, "paléo-assyriens”, 102.

168 Erol, Kültepe Tabletleri XI- $a, 136-138$.

169 Nurgül Yıldırım, "Kültepe Metinlerinde Geçen Dulbātum Kelimesi”, Archivum Anatolicum, C. 9, S. 1, (2006), 75.

170 Suzan Saygın, “Tuz”, Metro Gastro, C. 37, (2007), 70-71. 
Anadolu'nun jeolojik yapısı birçok bölgede doğal tuz yataklarının oluşmasına ve pek çok deniz ve gölden tuz elde edilmesine imkân vermiştir. ${ }^{171}$ Orta Anadolu'daki Tuz Gölü ve Çankırı Balıbağ yakınlarındaki kaya tuzu işletmesi Anadolu'daki çok eski çağlardan beri bilinen tuz kaynaklarıdır. Anadolu'da yakın zamanlara kadar hiçbir tuz kaynağında arkeolojik kazı ya da araştırma yapılmamış olsa da bu kaynakların Koloni ve Hitit dönemlerinde bilindiği Eski Asurca ve Hititçe belgelerden anlaşılmaktadır. ${ }^{172}$

Tuz, Eskiçağlarda besin maddesi olarak yemeklerde, besinlerin ve hayvanların derisinin saklanmasında, tıpta ve hatta ritüellerde kullanılmıştır. Kültepe metinlerinde țābtum ${ }^{173}$ olarak geçen tuz, besin ihtiyacını karşılamak için küçük miktarlarda, ticaretini yapmak için ise büyük miktarlarda satın alınmıştır. Metinlerde tuzun karpatum kabı ve litre ile ölçülerek satıldığı anlaşılmaktadır. Tuzun litre ile ölçülmesi, öğütülmüş olduğunu gösterir ki, Kültepe kazılarında bulunan öğütme taşları bunun kanıtıdır. ${ }^{174}$

Kayseri'nin 40 km kuzeydoğusunda Sarığlan ilçesi sınırlarında yer alan Tuzla Gölü bölge için önemli bir tuz kaynağıdır. ${ }^{175}$ Bu kaynağın Koloni Dönemi’nde Kaniš sakinleri tarafından tuz temini için kullanılmış olası yüksek ihtimaldir.

Değişik bitkileri, hayvansal ürünleri ve baharatları karıştırarak yemek yapmanın geçmişi Epipaleolitik (Mezolitik) Çağ başlarına kadar geriye dayanmaktadır. ${ }^{176} \mathrm{Bu}$ çağdan itibaren insanoğlu acı, tatlı, ekşi ve tuzlu gibi tatları elde etmek ve besinlerin lezzetini artırmak için hoş kokulu bitkileri kullanmaya başlamıştır. Yemeklere baharat eklenmesi yüksek bir damak tadının ve gelişmiş bir mutfak kültürünün varlığına işaret etmektedir. ${ }^{177}$ Yemeklerin vazgeçilmez lezzet kaynağı olan baharatların bazı çeşitlerinin Eski Anadolu mutfağında da kullanıldığını biliyoruz. Kültepe metinlerinde kaydedilmiş olan baharatlara örnek olarak kamūnum 178 "kimyon", kisibirrītum ${ }^{179}$ "kişniş", azupīrum/azappurum ${ }^{180 ~ " s a f r a n ” ~ v e ~ b i r ~ k e k i k ~ t u ̈ r u ̈ ~ o l d u g ̆ u ~ d u ̈ s ̧ u ̈ n u ̈ l e n ~}$ kudimmum gösterilebilir. ${ }^{181}$

\section{Sonuç}

İnsanların üzerinde yaşadığı coğrafyanın iklimi, florası ve faunası en eski dönemlerden itibaren beslenme alışkanlıkları üzerinde etkili olarak mutfak kültürlerini şekillendirmiştir. Bulunduğu coğrafya açısından bu konuda oldukça talihli olan Anadolu, zengin bir flora ve faunaya sahip olmuştur. Hayvan ve bitki türlerindeki çeşitlilik, tarih boyunca bu topraklar üzerinde yaşamış toplulukların mutfak kültürlerindeki zenginliğin ana kaynağı olmuştur. Arkeolojik buluntular, yazılı

171 Esma Öz, "Çivi Yazılı Belgelere Göre Eski Anadolu Mutfağında Bir Besin Maddesi: Tuz”, History Studies, C. 3, S. 3, (2011), 310.

172 Albayrak, Solak ve Uhri, Hitit Mutfăğ, 183.

173 CAD T, 10.

174 Öz, "Tuz”, 315.

175 Tamer Özlü, Sercan Gündüz ve Savaş Çağlak, “Tuzla Gölü Havzası'nın (Kayseri) Uygulamalı Jeomorfolojisi”, Studies of the Ottoman Domain, C. 7, S. 12, (2017), 256.

176 Uhri, Mutfak Kültürünün Kökenleri, 43.

177 Kılıç, Duymuş, “Anadolu'da Besin Maddeleri”, 347-348.

178 CAD K, 131.

179 CAD K, 420.

180 CDA, 33.

181 Michel, "paléo-assyriens", 105; Albayrak, "Besin Maddeleri”, 65; K1lı̧, Duymuş, "Anadolu'da Besin Maddeleri”, 348; Öz, Tarım ve Hayvancilık, 4-5. 
kaynaklar, arkeobotanik ve zooarkeolojik çalışmalar sonucunda elde edilen verilerle Anadolu' daki zengin bitki ve hayvan varlığı göz önünde bulundurularak en eski dönemlerden itibaren bu topraklardaki toplulukların mutfak kültürlerinin tek düze olmadığı söylenebilir. Ancak Kültepe'de bulunan yaklaşık 23.500 tabletten neşredilenler arasında dönemin mutfak kültürü hakkında detaylı ve doğrudan bilgi içeren kaynak ne yazık ki yetersiz kalmaktadır. Bunun başlıca sebebi Anadolu'ya ticari amaçlarla gelen Asurlu tüccarların kayıtlarındaki önceliği ticari içeriklere vermiş olmasıdır. $\mathrm{Bu}$ nedenle Kültepe metinleri içerisinde, Koloni Dönemi mutfağıyla ilgili bilgileri kısmen masraf kayıt belgeleri, borç vesikaları ve kişisel mektuplardan elde etmekteyiz. Kültepe'de gerçekleştirilen arkeolojik kazılarda ele geçirilen buluntular, son yıllarda yapılan arkeobotanik ve zooarkeolojik çalışmaların ortaya çıkardığı veriler, tabletlerdeki sınırlı bilgilerle birleştirildiğinde bazı sonuçlara ulaşmak mümkün olmuştur.

Koloni Dönemi Anadolu'sunda hem Asurlu hem de yerlilerin benzer şekilde beslenerek protein, karbonhidrat, yağ, lif, vitamin ve mineral içerikli bir besin diyetlerinin olduğunu söyleyebiliriz. Muhtelif tahıl türlerini tanıyan Kaniš sakinleri evlerde bulunan öğütme taşlarını kullanarak tahıllardan yan ürünler elde etmişlerdir. Kültepe metinlerine göre tahıllardan elde edilen besinlerden en fazla tüketilen iki ürün, ekmek ve bira çeşitleri olmuştur. Çivi yazılı metinlerin yanı sıra Kültepe'de gerçekleştirilen zooarkeolojik çalışmalardan elde edilen bilgiler, Kaniš sakinlerinin sofralarında hayvansal besin maddelerine de yer verdiğini göstermektedir. Hem Asurlular hem de yerliler arasında koyun, keçi, sı̆̆ır ve domuz en fazla tüketilen besi hayvanları olmuştur. Kültepe metinlerinde etin tüketim şekline dair diğer besin maddelerine göre daha fazla bilgi yer almaktadır. Yerli kadınlarla evli olan Asurlu tüccarların evlerinde hayvan besiciliği yaparak et ihtiyacını karşıladığı bilinirken, Anadolu'da yalnız olan tüccarlar ticaret ile meşgul oldukları için evde besi hayvanı bakacak vakit ve imkâna sahip olamamışlar bu nedenle eti muhtemelen satın alarak temin etmişlerdir. Nitekim Kültepe metinlerinde pişmiş ya da pişmemiş et satın alınmasıyla ilgili kayıtların bulunması bu kanıyı doğrular niteliktedir. Kültepe metinleri hayvanların etleri dışında iç yağlarının da mutfaklarda kullanıldı̆̆ını göstermektedir. Belgelerde çok sayıda besi hayvanından bahsedilirken süt ve süt ürünlerine dair kayıt olmaması oldukça ilginçtir. Ancak bu, Koloni Dönemi'nde süt ve süt ürünlerinin tanınmadığı şeklinde yorumlanmamalıdır. Kültepe'de bulunan çanak çömleğin zenginliği ve bunlar üzerinde karbon izotop incelemelerinin henüz yeterince yapılamamış olması süt ve süt ürünleri tüketimi hakkında bilgi edinmemize engel olurken, Kültepe metinlerinde ticaretinin de yapıldığ ürünlerini bildiğini kanıtlaması açısından oldukça önemlidir. Bilindiği üzere süt ve sütten elde edilen besinler çabuk bozulabilir olduğu için nakliyesi ve uzun süre muhafazası kolay değildir. Bu nedenle ticareti yapılamayan bu besinler muhtemelen hane halkı tarafından üretilip, kısa sürede tüketiliyordu. Kültepe'de metinlerinde geçen birçok bitkinin ismi henüz anlamlandırılamadığı için bu bitkilerin günümüzdeki karşılıklarını bilmiyoruz. Kültepe'de gerçekleştirilen arkeobotanik çalışmalara kadar fındığın burada tanındığı ve tüketildiğine dair bir kanıt yoktu. Koloni Dönemi'ne ait kömürleşmiş örnekler içerisinde rastlanılan kabuklu fındık kalıntıları metinlerde varlığı henüz netlik kazanmayan findığın tüketildiği kanıtlaması açısından önemlidir. Kayseri ve çevresinin doğal florasına ait olmayan bu meyvenin Karadeniz kıyılarından ticaret vasıtayla Kaniš’e getirildiği düşünülmektedir. Kültepe'de yapılacak olan arkeobotanik, zooarkeolojik ve karbon izotop incelemelerin artması, burada gerçekleştirilecek kazılar sonucu elde edilecek yeni bulguların ortaya çıkması ve konu ile ilgili yeni metinlerin neşredilmesi sonucunda ilerleyen zamanlarda dönemin mutfak kültürü hakkında daha fazla bilgi edinilmesi muhtemeldir. 


\section{Kaynakça}

A Concise Dictionary of Akkadian (CDA).

Akkadisches Handwörterbuch (AHw).

Abak, Kazım. Türkiye'de Domatesin Dünü, Bugünü ve Yarını, Türkiye Tohumcular Birliği Dergisi, C. 5, S.17, 2016, s. 8-13.

Albayrak, Asuman, Solak, Ülkü M. ve Uhri, Ahmet. Deneysel Bir Arkeoloji Çalışması Olarak Hitit Mutfağı, Metro Kültür Yayınları, İstanbul 2008.

Albayrak, İrfan. “Kültepe’den Değişik Bir Masraf Listesi”, Archivum Anatolicum, C. 5, S. 12002 , s. $1-10$.

Albayrak, İrfan. "Kültepe Metinlerinde Geçen Besin Maddeleri”, IV. Kayseri ve Yöresi Tarih Sempozyumu Bildirileri, 2003, s. 59-66.

Albayrak, İrfan. “Kültepe'de Ele Geçen Vasiyetnamelere Göre Eski Anadolu'da Miras Anlayışı”, ICANAS 38, 2012, s. 137-149.

Alp, Sedat. Hitit Güneşi, Tübitak Yayınları, Ankara 2003.

Atak, Mehmet. "Buğday ve Türkiye Buğday Köy Çeşitleri”, Mustafa Kemal Üniversitesi Ziraat Fakültesi Dergisi, C. 22, S. 2, 2017, s. 71-88.

Atıc1, Levent. "Food and Ethnicity at Kültepe-Kanesh: Preliminary Zooarchaeological Evidence”, ed. L. Atıcı, F. Kulakoğlu, G. Barjamovic, A. Fairbairn, Current Research at Kültepe/ Kanesh: An Interdisciplinary and Integrative Approach to Trade Networks, Lockwood Press, Atlanta, 2014, s. 195-212.

Atıc1, Levent. "The Secondary Products Revolution in Light of Textual Evidence from Kültepe-Kanesh Central Turkey”, ed. H. Greenfieldpp, Animal Secondary Products: Domestic Animal Exploitation in Prehistoric Europe, the Near East and the Far East, Oxbow Books Press, Oxford, 2014, s. 233-252.

Balkan, Kemal."Cancellation of Debts in Cappadocian Tablets from Kültepe”, Anatolian Studies Presented to Hans Gustav Gütterbock on the Occasion of his 65th Birthday'den ayrı basım, (PIHANS), İstanbul 1974, s. 29-41.

Barjamovic, Gojko, Patricia Jurado Gonzalez, Chelsea Graham, Agnete W. Lassen, Nawal Nasrallah, Pia M. Sörensen. "Food in Acient Mesopotamia Cooking the Yale Babylonian Culinary Recipes”, ed. A. W Lassen, E. Frahm, K. Wagensonner, Ancient Mesopotamia Speaks Highlights from the Yale Babylonian Collection, Yale Peabody Museum of Natural History, New Haven, 2019, s. 108-125.

Bayram, Mustafa. "Bulgur Around the World", Cereal Foods World, C. 45, 2000, s. 80-82.

Bottero, Jean. "Dünyanın En Eski Mutfağı”, ed. J. Bottero, Eski Yakındoğu Sümer'den Kutsal Kitap'a, Dost Kitapevi, Ankara 2005.

Civitello, Linda. Mutfak ve Kültür İnsanın Beslenme Tarihi, Bilim ve Sanat Yayınları, Ankara 2019.

Dercksen, J. Gerrit. "Observations on Land Use and Agriculture in Kaneš”, ed. C. Michel, 
Old Assyrian Studies in Memory of Paul Garelli, Old Assyrian Archives, Nederlands Instituut Voor Het Nabije Oosten, Leiden, 2008, s. 139-157.

Dercksen, J. Gerrit. "Subsistence, Surplus and the Market for Grain and Meat at Ancient Kanesh", Altoriental Forsch, C. 3, S. 1, 2009, s. 86-102.

Donbaz, Veysel. “Old Assyrian Terms for Bread (akalu, kirrum)”, ed. H. Behrend, D. Loading, M. Roth, DUMU.É.DUB.BA.A Studies in Honor of Ake W. Sjöberg, University of Pennsylvania Museum, Philadelphia 1989, s. 91-97.

Donbaz, Veysel. "Some Remarkable Contracts of I-B Period Kültepe Tablets II", ed. E. Porada, M. Machteld J., T. Özgüç, Aspects of Art and Iconography: Anatolia and its Neighbors: Studies in Honor of Nimet Özgüc, Türk Tarih Kurumu, Ankara 1993, s. 131- 154.

Donbaz, Veysel. “One 1-B Kültepe Text Concerning Onions”, ed. H. Klengel and J. Renger, Landwirtschaft im Alten Orient. Ausgewählte Vorträge der XLI. Rencontre Assyriologique Internationale (CRRAI 41), Dietrich Reimer Verlag, Berlin 1994, s. 149-153.

Duymuş Florioti, H. Hande. "Asur Sarayında Beslenme: Yeni Asur Devri”, Tarih Okulu Dergisi, C. 11, S. 34, 2018, s. 25-42.

Emre, Kutlu. "Hitit Sanatında Kültepe/Kaniş’in İzleri”, ed. F. Kulakoğlu, S. Kangal, Anadolu'nun Özsözü Kültepe Kaniş-Karumu, Kayseri Büyükşehir Belediyesi Kültür Yayınları, Kayseri, 2011, s. 154-159.

Erol, Hakan. Kültepe Tabletleri XI-a, Türk Tarih Kurumu, Ankara 2018.

Ertem, Hayri. Boğazköy Metinlerine Göre Hititler Devri Anadolu’sunun Floras1, Türk Tarih Kurumu, Ankara 1987.

Fairbairn, Andrew. "Preliminary Archaeobotanical Investigations of Plant Production, Consumption, and Trade at Bronze Age Kültepe-Kanesh", ed. L. Atıc1, F. Kulakoğlu, G. Barjamovic, A. Fairbairn, Current Research at Kültepe/Kanesh: An Interdisciplinary and Integrative Approach to Trade Networks, Lockwood Press, Atlanta 2014, s. 177-193.

Fairbairn, Andrew, Kulakoğlu, Fikri ve Atıc1, Levent. "Archaeobotanical Evidence for Trade in Hazelnut (Corylus sp.) at Middle Bronze Age Kultepe (c. 1950-1830 BC), Kayseri Province, Turkey", Vegetation History and Archaeobotany, C. 23, S. 2, 2014, s. 167-174.

Gökçek, L. Gürkan. "Kültepe Metinlerinde Geçen Kaplar”, Archivum Anatolicum, C.6, S.2, 2003, s. 73-87.

Gökçek, L. Gürkan. “Asur Ticaret Kolonileri Çağı’nda (M.Ö. 1975-1723) Anadolu’da Hayvancilık ve Hayvan Ticareti”, Archivum Anatolicum, C. 7, S. 1, 2004, s. 59-78.

Günbattı, Cahit. "Kültepe Tabletlerine Göre, Kadınların Ticari Faaliyetleri Hakkında Gözlemler”, XI. Türk Tarih Kongresi, Türk Tarih Kurumu, Ankara 1994, s. 191-200.

Günbatt1, Cahit. Kültepe Tabletleri X, Türk Tarih Kurumu, Ankara 2016.

Güveloğlu, Ali. “Eski Doğu Toplumlarında Beslenme ve Damak Tadı”, ed. İ. Albayrak, H. Erol, M. Çayır, Cahit Günbattı’ya Armağan, Ankara Üniversitesi Dil ve Tarih-Coğrafya Fakültesi Yayınları, Ankara 2015, s. 119-134. 
Hecker, Karl, Guido, Kryszat, Lubor, Matouš. Kappadokische Keilschrifttafeln aus den Sammlungen der Karlsuniversität Prag, Karlsuniversiätt, , Prague 1998.

Işın, Priscilla Mary. Avcılıktan Gurmeliğe Yemeğin Kültürel Tarihi, Yapı Kredi Yayınları, İstanbul 2020.

Kılıç, Yusuf, Duymuş, H. Hande. "M.Ö. II. Bin Yılda Anadolu'da Besin Maddeleri (Hitit Öncesi Toplumlarda ve Hititlerde)", ed. S. Sertçelik, H. Eroğlu, M. Sarı Güven, Prof Dr. Yavuz Ercan'a Armağan, Turhan Kitapevi, Ankara 2008, s. 335-354.

Kuzuoğlu, Aliye, "Koloni Çă̆ı'’nda Anadolu ve Asur'da Kadın”, Gazi Üniversitesi Sosyal Bilimler Enstitüsü Eskiçağ Tarihi Bilim Dalı, Yüksek Lisans Tezi, Ankara 2004.

Larsen, M. Trolle. The Old Assyrian City-State and Its Colonies, Akademisk Forlag, Copenhagen 1976.

Larsen, M. Trolle. The Aššur-nādā Archive, Nederlands Instituut Voor Het Nabije Oosten, Leiden 2002.

Limet, Henri. "The Cuisine of Ancient Sumer", The Biblical Archaeologist, C. 50, S. 3, 1987, s. $132-147$.

Michel, Cecile. "A table avec les marchands paléo-assyriens", ed. H. Waetzoldt and H. Hauptmann, Assyrien im Wandel der Zeiten, Compte rendu des Rencontres Assyriologiques Internationales (CRRAI 39), Heidelberger Orientverlag, Heidelberger 1997, s. 95-113.

Michel, Cecile."Les Malheurs de Kunnaniya, Femme de Marchand”, Archivum Anatolicum, C. 3, S. 1, 1997, s. 239-253.

Michel, Cecile. “Asur ve Kaniş'in Kadınları”, ed. F. Kulakoğlu ve S. Kangal, Anadolu'nun Özsözü Kültepe Kaniş-Karumu, Kayseri Büyükşehir Belediyesi Kültür Yayınları, Kayseri 2011, s. $124-133$.

Müller-Karpe, Vuslat. “Anadolu'da Bronz Çağında Bira”, ed. Ü. Yalçın, C. Pulak ve R. Slotta, Uluburun Gemisi 3000 Y1l Önce Dünya Ticareti, Ege Yayınları, İstanbul 2006, s. 173-186.

Nemet-Nejat, K. Rhea. "Women in Ancient Mesopotamia", ed. B. Vivante, Women's Role in Ancient Civilizations, Greenwood Press, Westport 1999, s. 85-114.

Ökse, A. Tuba. "Modern Mutfakların Eski Anadolu'daki Öncüleri”, Yemek ve Kültür, C. 46 2017, s. 76-88.

Öz, Esma. "Kültepe Tabletlerine Göre Asur Ticaret Kolonileri Döneminde Anadolu'da Üzüm Yetiştiriciliği ve Bağcılık”, Gazi Akademik Bakış, C. 5, S. 9, 2011, s. 285-294.

Öz, Esma. "Çivi Yazılı Belgelere Göre Eski Anadolu Mutfağında Bir Besin Maddesi: Tuz", History Studies, C. 3, S. 3, 2011, s. 309-318.

Öz, Esma. "Kültepe Tabletlerinde Geçen hašlātum Kelimesi Üzerine Bir Değerlendirme", Tarih Araştırmaları Dergisi, S. 31, C. 51, 2012, s. 159-164.

Öz, Esma. Kültepe Metinleri Işı̆̆ında Eski Anadolu'da Tarım ve Hayvancılık, Türk Tarih Kurumu, Ankara 2014.

Özbek, Metin. Çayönü'nde İnsan, Arkeoloji ve Sanat Yayınları, İstanbul 2004. 
Özbek, Metin. Beslenme Kültürü ve İnsan, İmge Kitapevi, Ankara 2020.

Özgüç, Tahsin. Kültepe-Kaniş, Asur Ticaret Kolonilerinin Merkezinde Yapılan Yeni Araştırmalar, Türk Tarih Kurumu, Ankara 1959.

Özgüç, Tahsin. Kültepe Kaniš/Neša, Yapı Kredi Yayınları, İstanbul 2005.

Özlü, Tamer, Gündüz, Sercan ve Çağlak, Savaş. “Tuzla Gölü Havzası'nın (Kayseri) Uygulamal1 Jeomorfolojisi”, Studies of the Ottoman Domain, C. 7, S. 12, 2017, s. 1-14.

Sagona, Antonio ve Zimansky, Paul. Arkeolojik Veriler Işığında Türkiye'nin En Eski Kültürleri M.Ö. 1.000.000-550, Arkeoloji ve Sanat Yayınları, İstanbul 2018.

Saygın, Suzan. “Tuz”, Metro Gastro, C. 37, 2007, s. 70-72.

Sturm, Thomas. "allānū- Haselnüsse als Delikatesse im kārum-zeit/ichen Handel von Anatolien nach Nordmesopotamien (ca 1930-1730 v. Chr.)", Altorient Forsch, C.35, 2008, 296311.

The Assyrian Dictionary of the Oriental Institute of the University of Chicago (CAD).

The Electronic Pennsylvania Sumerian Dictionary (Epsd) (Http://Psd.Museum.Upenn.Edu/ Epsd/İndex.Html).

Uhri, Ahmet. Anadolu Mutfak Kültürünün Kökenleri, Ege Yayınları, İstanbul 2016.

Ünal, Ahmet. "Erken Anadolu Toplumlarında Günlük Yaşamda ve Kült Yaşamında Bira”, ed. Ü. Yalçın, C. Pulak ve R. Slotta, Uluburun Gemisi 3000 Yıl Önce Dünya Ticareti, Ege Yayınları, İstanbul 2006, s. 169-172.

Vigne, Jean Denis and Helmer, Daniel. "Was Milk a "Secondary Product" in the Old World Neolithisation Process? Its Role in the Domestication of Cattle, Sheep and Goats", Anthropozoologica, C. 42, S. 2, 2007, s. 9-40.

Wilcke, Von Claus. "Die Altassiyrische Testamente", Zeitschrift für Assyriologie (ZA), Band 66, 1976, s. 196- 233.

Yakar, Jak, Eski Anadolu Toplumunun Arkeolojideki Yansımaları I, Homer Kitapevi, İstanbul 2014.

Yazıc1, Hakkı. İç Anadolu Bölgesi Coğrafyası, Nobel Kitapevi, Ankara 2002.

Yıldırım, Nurgül. "Kültepe Metinlerinde Geçen Dulbātum Kelimesi”, Archivum Anatolicum, C. 9, S. 1, 2006, s. 73-78. 


\section{Fotoğraflar}

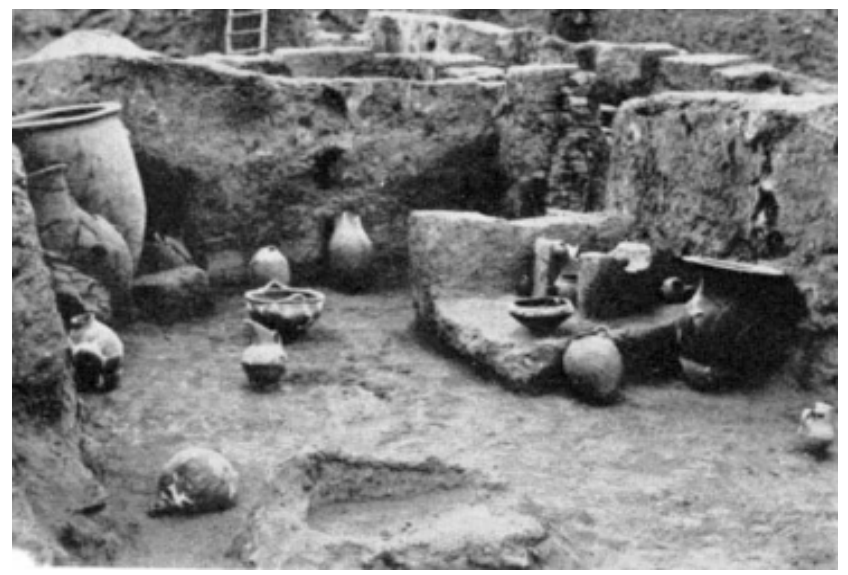

Res. 1: Kültepe kazılarında ortaya çıkarılan bir Kaniš mutfağı (Özgüç 1959: Lev. XXI,2).

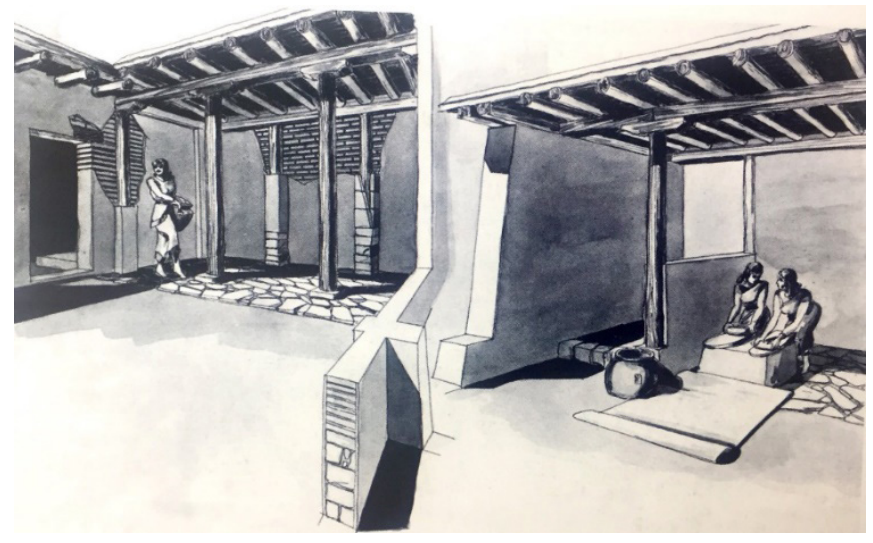

Res. 2: Kaniš’te öğütme işini yapan kadınlar (Özgüç 2005: 56).

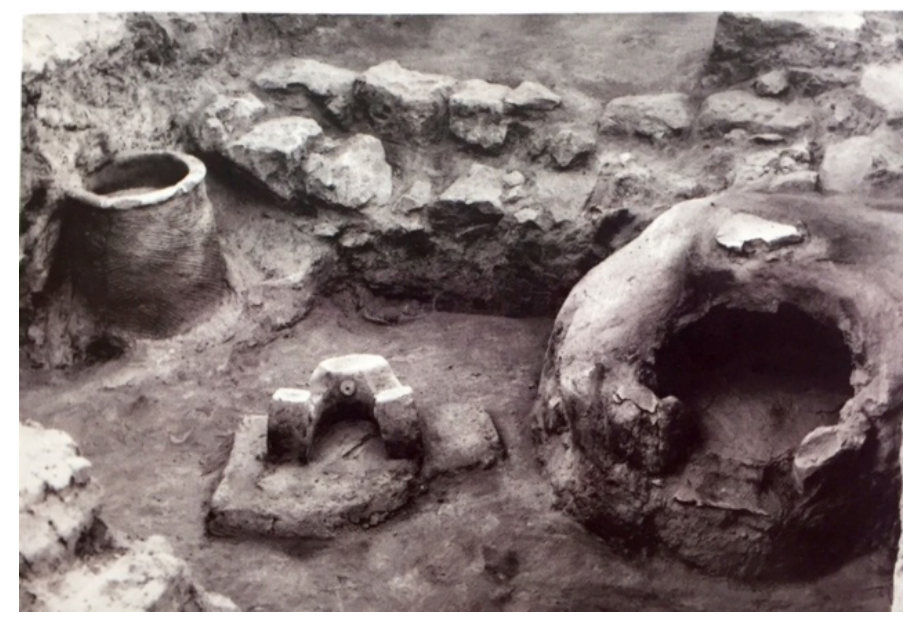

Res. 3: Kültepe'de neredeyse her evde bulunan ocak, tandır ve firın örnekleri (Özgüç 2005, 63). 


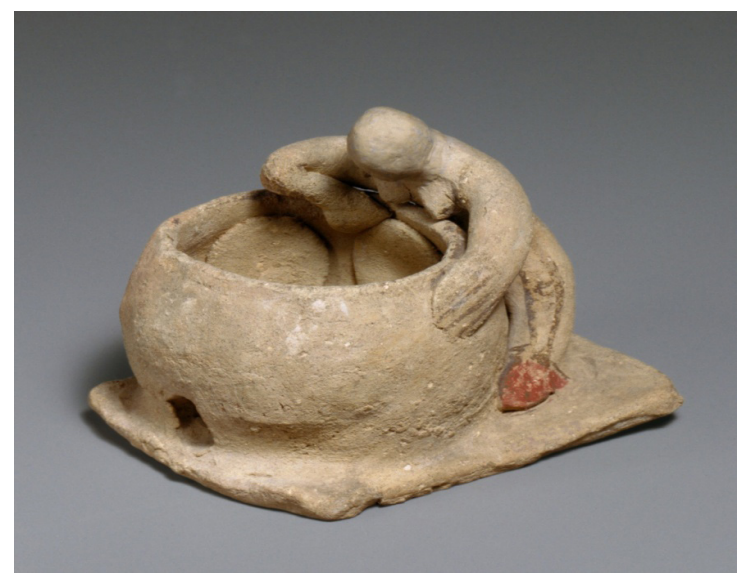

Res.4: Tandırda ekmek pişiren kadın (https://www.metmuseum.org/art/collection/ search/241310).

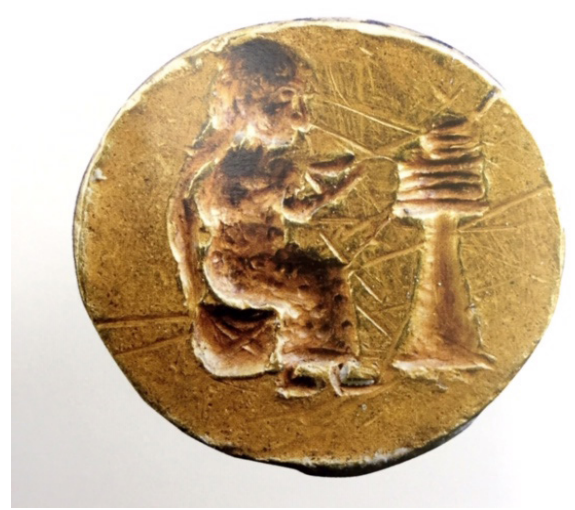

Res. 5: Kültepe Ib katında bulunan altın damga mühür üzerinde tahtında oturan tanrıça ve karşısındaki altar üzerinde betimlenen bazlama şeklindeki ekmekler

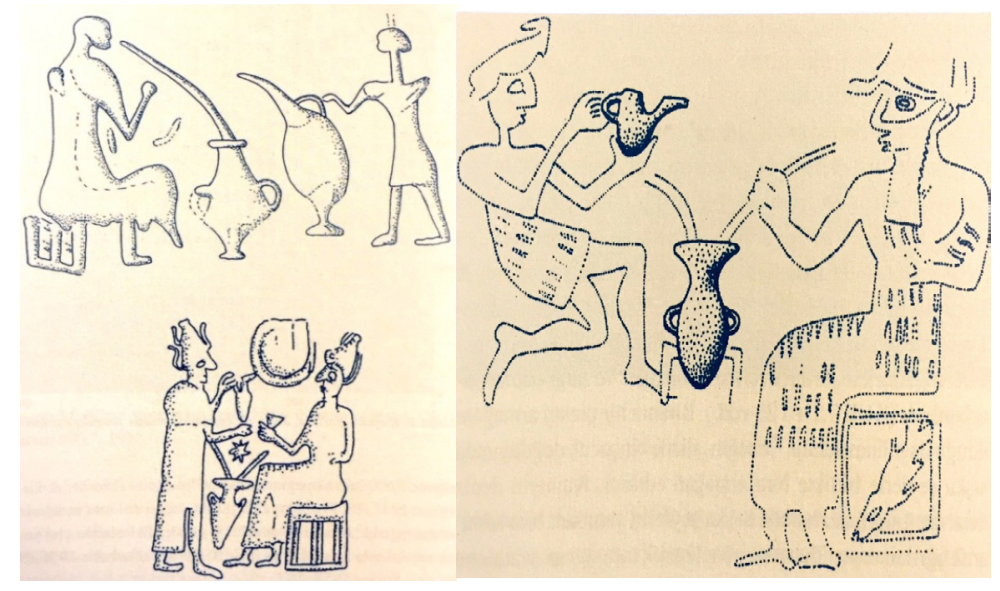

Res. 6: Kültepe'den bira içme sahnesiyle bezeli mühür baskıları (Müller-Karpe 2006, 171; 173). 


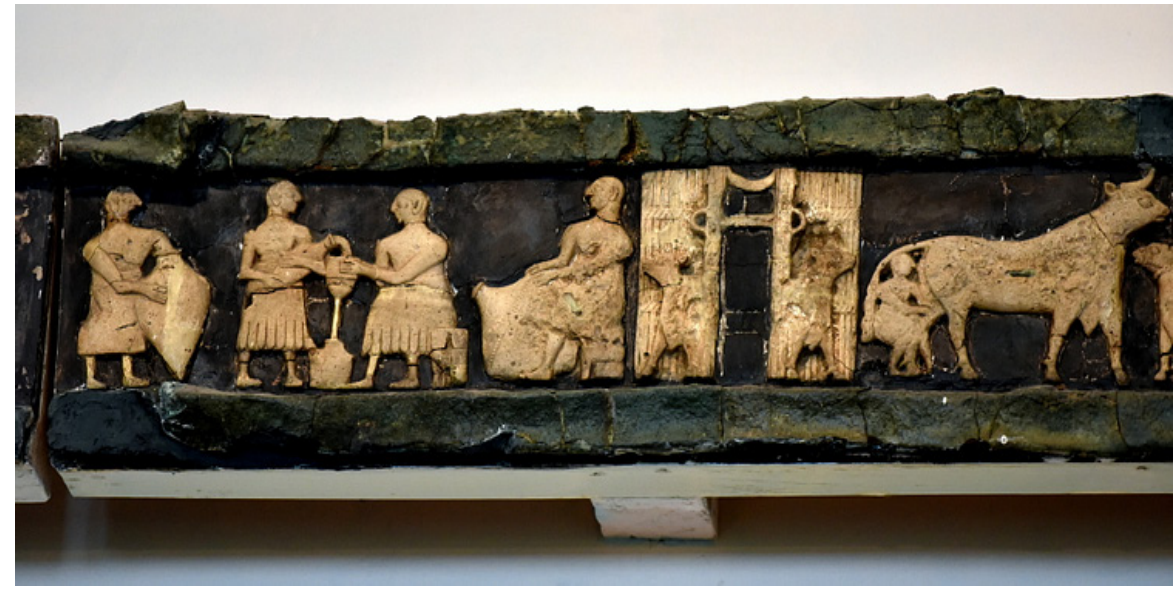

Res. 7: Mezopotamya'da erken dönemlerde süt kullanımının betimlendiği taş kabartma (Limet 1987, 136).

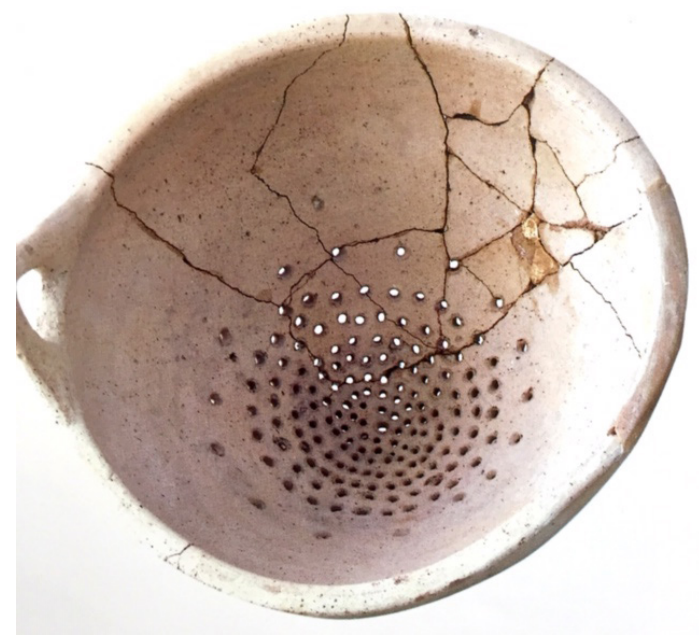

Res. 8: Kültepe II. yapı katında bulunan süzgeç formunda kap (Özgüç 2005: 148). 